\title{
Integrated approaches to groundwater quality assessment and hydrochemical processes in Lagos, Nigeria
}

\author{
Isaiah Sewanu Akoteyon ${ }^{1} \cdot$ Isaac Idowu Balogun ${ }^{2} \cdot$ Alabi S. Okanlawon Soneye $^{2}$
}

Received: 25 September 2017 / Accepted: 5 October 2018 / Published online: 17 October 2018

(c) The Author(s) 2018

\begin{abstract}
Integrated approaches of water quality indices, multivariate statistical analysis, and geostatistical technique were applied to examine the groundwater quality and hydrochemical processes in Lagos, Nigeria. Fifteen samples each were randomly collected from peri-urban, rural, and urban settlements totaling 45 samples from protected dug wells during dry and wet seasons. Samples were analyzed for physicochemical parameters, anion, and cation using standard method. The result shows that $95.6 \%$ of the samples during the dry season had $\mathrm{pH}$ below the minimum guideline for drinking water. Factor analysis explained $73.5 \%$ and $84.2 \%$ of the variance during dry and wet seasons, respectively, and extracted two factors-salinity and weathering of minerals. Gibbs plot indicates rock-weathering process as the mechanism controlling the groundwater system. Drinking water quality index shows excellent quality. Revelle index indicates that $6.6 \%$ of the samples are strongly affected by salinity during the wet season. One-quarter of sample indicate very severe corrosion based on the water stability index in both seasons. The Piper's plot delineated four facies with primary hardness and mixed waters being the dominant during the dry and wet seasons, respectively. The study concludes that the groundwater is suitable for drinking. The study contributes to knowledge in the mapping of groundwater salinization and water stability indices and delineation of water types for information dissemination with a view to ensuring effective groundwater quality management. A policy that will ensure adequate protection of groundwater pollution from leachates, salinity, and anthropogenic impacts was recommended for sustainable groundwater use in the region.
\end{abstract}

Keywords Groundwater quality $\cdot$ Hydrochemical processes $\cdot$ Integrated approach $\cdot$ Lagos—Nigeria

\section{Introduction}

Groundwater is one of the vital resources that require adequate protection from anthropogenic pollution sources. Globally, the alarming rate of anthropogenic activities and climate change phenomenon has impacted significantly on the quality of both the surface and groundwater resources (Arian et al. 2008; Bu et al. 2010). Groundwater quality can be influenced by the lithology, water-rock interaction, and changes in space and time (Todd and Larry 2005; Srinivasamoorthy et al. 2008; Bhattacharya and Bundschuh 2015).The continuous rise in anthropogenic activities, uncoordinated

Isaiah Sewanu Akoteyon

isaiah.akoteyon@lasu.edu.ng

1 Department of Geography and Planning, Lagos State University, PMB 0001 LASU Post Office, Ojo, Nigeria

2 Department of Geography, University of Lagos, UNILAG Post Office, Akoka, Nigeria development, has led to an increase in point source pollutants such as leachates from dumpsite, seepage from the septic tank, and municipal sewage plants among others. Current emerging pollutants from agro-based activities such as nitrate, pesticides, and other heavy metals and persistent organic products (POPs), volatile organic carbon (VOCs) among others pose serious challenges to human health and the sustainability of groundwater (Kumazawa 2002; Jalali and Kolahchi 2008; Balogun and Adegun 2013; Salami and Susu 2013; Ocheri et al. 2014).

Globally, water-related diseases are the leading causes of morbidity and mortality in many parts of the developing world, with about 2-12 million deaths per year (Gleick 2002; WWAP 2003). Due to the present health and environmental challenges resulting from water-related diseases, the assessment of water quality, therefore, becomes very imperative because it serves as a vital tool for sustainable water resources management strategies (Zhou et al. 2007; $\mathrm{Bu}$ et al. 2010). The approaches of water quality assessment 
and hydrochemical processes abound in the literature. For instance, the application of water quality indices (WQI) serves as a veritable scientific tool for assessing the suitability of water quality for various uses in an integrated manner (Balogun et al. 2012). The WQIs also helps to reveal the effects of individual groundwater parameters on the overall water quality in a given location (Sarala and Uma Mageswari 2014). The WQIs also show the variation and the possible trends both spatially and temporarily for easy information dissemination to the public (Bharti and Katyal 2011; Akoteyon 2013). Apart from WQI, the applications of water stability index (WSI), such as Langelier saturation index (LSI), Ryznar stability index (RSI), Puckorius scaling index (PSI), and Aggressive index (AI) (Gholizadeh et al. 2017; Choi et al. 2015; Chung et al. 2004; Kurdi et al. 2015), serve as very useful tools to assess corrosion and scaling potential of water resources globally. Studies have shown that LSI is one of the most widely used indicators for determining scale formation potential in water supply and drinking water networks (Gholizadeh et al. 2017; Maeng et al. 2015; Alsaqqar et al. 2014). Beyond the problems of corrosion and scaling, groundwater salinization in coastal areas has continued to be a major concern of water resources management in these regions. This has led to the development of various indices, for example applications of GALDIT index Lobo Ferreira et al. (2005), Revelle index (Revelle 1941), and ionic ratios of electrical conductivity, sodium/ chloride, magnesium/calcium (Narany et al. 2014). The use of Revelle index has been proven to be a very veritable tool in evaluating groundwater salinization in both the tropical and arid regions (Aris et al. 2009; Tziritis et al. 2009; Revelle 1941). Other relevant graphical techniques employed in groundwater quality assessment include Gibbs plot (Gibbs 1970), Schoeller (1964), Stiff (1951), Durov (1948), Piper (1944), Collins diagrams (Collins 1923). Piper's diagram has been extensively used in groundwater data set to delineate hydrochemical facies to reveal discernible patterns and trends in water quality for a better understanding of groundwater flow and geochemistry in an aquifer system (Dalton and Upchurch 1978).

Similarly, Gibbs plot has enhanced the interpretation of the effect of hydrogeochemical processes (i.e., precipitation, rock-water interaction, and evaporation) with the aim of providing knowledge on the source of water contamination and the interaction between rock and aquifer (Howladar et al. 2017; Boateng et al. 2016). There is a scanty study on a holistic application of water quality indices, chemometric methods, such as multivariate statistical analysis and geostatistical technique in the study area. This study applied water stability index with drinking water quality index, groundwater salinization with the chemometric method, such as multivariate statistical analysis and geostatistical technique. The methodology provides a reliable technique of data mining and source apportionment for better interpretation of water quality data which are difficult to evaluate using only elemental concentrations (Machiwal and Jha 2015). The study is also significant because it employed a novel method that delineates the sampling sites into distinct geographical strata, namely peri-urban, rural, and urban settlements beyond administrative boundaries for environmental quality assessment studies in Lagos, Nigeria. This study, therefore, seeks to examine the groundwater quality and hydrochemical processes using integrated approaches in Lagos, Nigeria. The study contributes to knowledge in the mapping of the distributional patterns of groundwater salinization and water stability index. It also identified the major mechanism controlling groundwater chemistry, sources of groundwater pollution and delineation of water types in the study area as baseline information for effective groundwater management.

\section{Study area}

The study site is located in the coastal plain sand (CPS) aquifer of Lagos, in parts of Southwestern Nigeria. It lies approximately on latitudes $6^{\circ} 30^{\prime} \mathrm{N}-6^{\circ} 40^{\prime} \mathrm{N}$ and longitudes $3^{\circ} 00^{\prime} \mathrm{E}-4^{\circ} 00^{\prime} \mathrm{E}$. The area is bounded by Ogun State in the east and north, the Atlantic Ocean in the south, and Benin republic in the west. It occupies about $73.63 \mathrm{~km}^{2}$ of land covering peri-urban, rural and urban settlements around Lagos metropolis, Ikorodu, Epe, and Badagry geographical regions (Fig. 1).

The climate of Lagos state is controlled by the tropical and continental air masses, which are associated with northeast and moisture-laden southwest winds, respectively. The movements of the air masses result in the two weather seasons, namely dry and wet seasons (Adepelumi 2009). The average temperature is $30^{\circ} \mathrm{C}$, while the mean annual rainfall is about $1532 \mathrm{~mm}$. The dominant vegetation is comprised of tropical swamp forest (freshwater and mangrove swamp forests and dry lowland rainforest; Akoteyon 2013). The topography of the area is comprised of troughs which are dominated by a system of the Island, sandbars, and lagoons, developed by barrier beaches associated with sand deposition (Adepelumi 2009). It has a lowland territory, very flat in its western portion and somewhat hilly in its eastern zone. The state is bisected and parallel to the ocean by the Lagos lagoon and Badagry creek. The northern section of the state is composed of lowlands in the west, flat hills in the east, and marshland of the Ogun River in the Centre. In the central region lies the Lagos metropolis, characterized by a densely populated settlement (Coode et al. 1997). The area is drained by various river systems, for example Ogun River in the center, the Ona River and Osun in the east, and the Yewa in the west, flowing southwards to join coastal lagoons (Akoteyon et al. 2010). The geology of the area lies solely in the Dahomey sedimentary basin and has no outcrop. The 


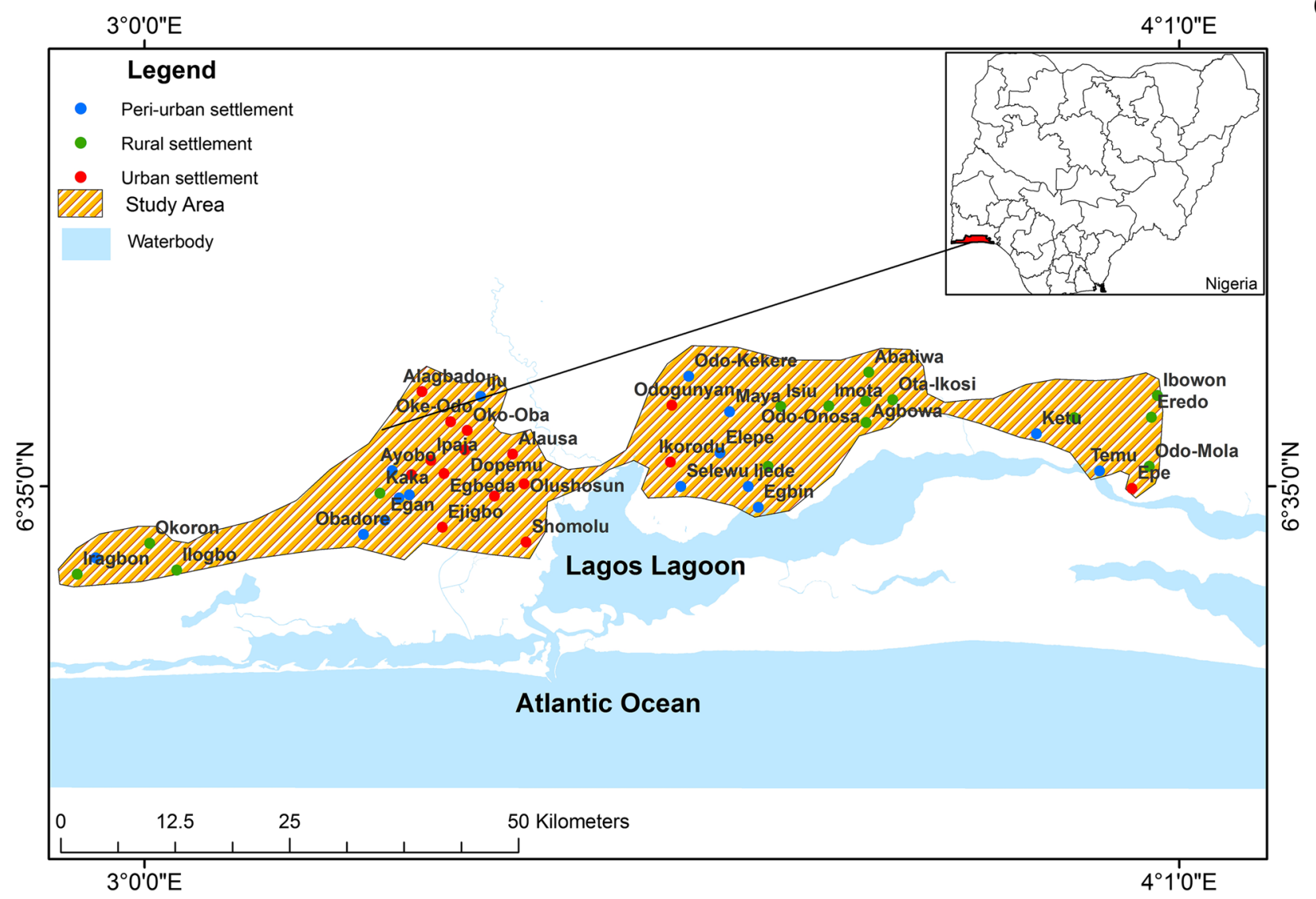

Fig. 1 The study area

geological sequence in the Dahomey basin extends from the Precambrian to recent (Coode et al. 1997). The upper sediments in the Dahomey Basin are underlain by coastal plain sands, also known as the Benin formation of the Quaternary age. Studies have shown that recent sediments occur along the coastal belt in the form of alluvial deposits along the major rivers in the coastal areas (Coode et al. 1997).

The hydrogeology of the CPS aquifer is composed of lenticular unconsolidated yellowish (ferruginous) to whitish sands with shale, clay, and sandy clay intercalations. The CPS formations consist of multi-aquifer systems arising from the alternation of sands and clay. The sand has artesian or sub-artesian characteristics. The sources of groundwater recharge in the CPS are through surface runoff and percolation from precipitation. More than $30 \%$ of groundwater supply in Lagos State taps water from the CPS to meet domestic, municipal, and industrial water demands (Akoteyon 2013). The aquifer is tapped for groundwater supply in Lagos through the establishment of the micro- and mini water works (Balogun et al. 2012). Lateral variations exist in the CPS aquifer due to its lithology and water quality. The CPS aquifer in Lagos is subdivided into four, namely recent sediment, upper CPS, lower CPS and the Abeokuta formation (Coode et al. 1997). The water table of the CPS ranged between $0.4-21 \mathrm{~m}$ with an annual fluctuation of less than $5 \mathrm{~m}$ (Akoteyon 2013).

Variation in the thickness of the recent and lower CPS aquifer ranged between $200 \mathrm{~m}$ and $250 \mathrm{~m}$, respectively, with mean groundwater storage of the first CPS aquifer estimated at $2.87 \times 103 \mathrm{~m}^{3}$ (Akoteyon 2013). The recent sediment is water table aquifer usually found along the coast and in the alluvial plains of the river valleys. The water table is shallow and has higher total dissolved solids (TDS), conductivity compared to the upper coastal plain sand (UCPS) and the lower coastal plain sand (LCPS). The shallow nature of the water table makes it vulnerable to contamination from sewage and waste disposal (Coode et al. 1997). Groundwater salinity in the aquifer varies from north to south (Akoteyon et al. 2010). Saltwater intrusion occurs into this aquifer with the second aquifer being fresh water-bearing in the northern and central parts of the state, while the southern coastal belt is characterized by saltwater (Akoteyon et al. 2010). 


\section{Materials and methods}

A total of fifteen groundwater samples each were collected from peri-urban labeled $\left(\mathrm{P}_{1}-\mathrm{P}_{15}\right)$, rural $\left(\mathrm{R}_{1}-\mathrm{R}_{15}\right)$ and urban $\left(\mathrm{U}_{1}-\mathrm{U}_{15}\right)$ settlements totaling 45 samples from protected dug wells (PDW) using random sampling technique during March 2012 — dry season—and July 2012 — wet season-to assess the quality, characterize the water type, and identify the hydrogeochemical processes operating within the groundwater system in the study (Fig. 2).

The groundwater samples were collected in one-liter polyethylene bottles. Prior to the sample collections, the bottles were washed with distilled water and thereafter rinsed with water to be sampled (APHA 1998). The groundwater samples were preserved in ice chests to minimize error during transit and taken to the Chemistry Department, University of Lagos for laboratory analyses, using standard procedure after APHA (1998). The parameters examined include $\mathrm{pH}$, electrical conductivity (EC), total dissolved solids (TDS), sodium $\left(\mathrm{Na}^{+}\right)$, potassium $\left(\mathrm{K}^{+}\right)$, calcium $\left(\mathrm{Ca}^{2+}\right)$, magnesium $\left(\mathrm{Mg}^{2+}\right)$, chloride $\left(\mathrm{Cl}^{-}\right)$, bicarbonate $\left(\mathrm{HCO}_{3}{ }^{-}\right)$, carbonate
$\left(\mathrm{CO}_{3}{ }^{-}\right)$, and sulfate $\left(\mathrm{SO}_{4}{ }^{2-}\right)$.Total hardness $(\mathrm{TH})$ was evaluated based on Fournier (1981) method as indicated in Eq. 1.

$\mathrm{TH}=2.5 \mathrm{Ca}(\mathrm{mg} / \mathrm{L})+4.1 \mathrm{Mg}(\mathrm{mg} / \mathrm{L})$

where $\mathrm{Ca}$-calcium, $\mathrm{Mg}$-magnesium.

Groundwater $\mathrm{pH}$, TDS, and EC were measured in situ using pHep and DiST EC HANNA single-parameter probe (HI7007 and HI98303), respectively. The TDS was measured using TDS-3 m HM Digital multi-parameter probe. The major ions were determined based on standard procedures after APHA (1998). Titration method was employed to determine calcium and magnesium based on standard EDTA $(0.01 \mathrm{M})$ solution. Chloride was determined by titration using standard silver nitrate. Bicarbonate and carbonates were evaluated titrimetrically using standard hydrochloric acid $(0.01 \mathrm{~N})$ solution. Flame photometer was employed to analyze potassium and sodium, and sulfate by spectrophotometer. The reliability test of the laboratory analyses of the major ions was subjected to internal consistency to identify inconsistencies using charge balance error (CBE) formula by Apello and Postma (2005) as indicated in Eq. 2. Generally, all the samples are within $\pm 5 \%$.

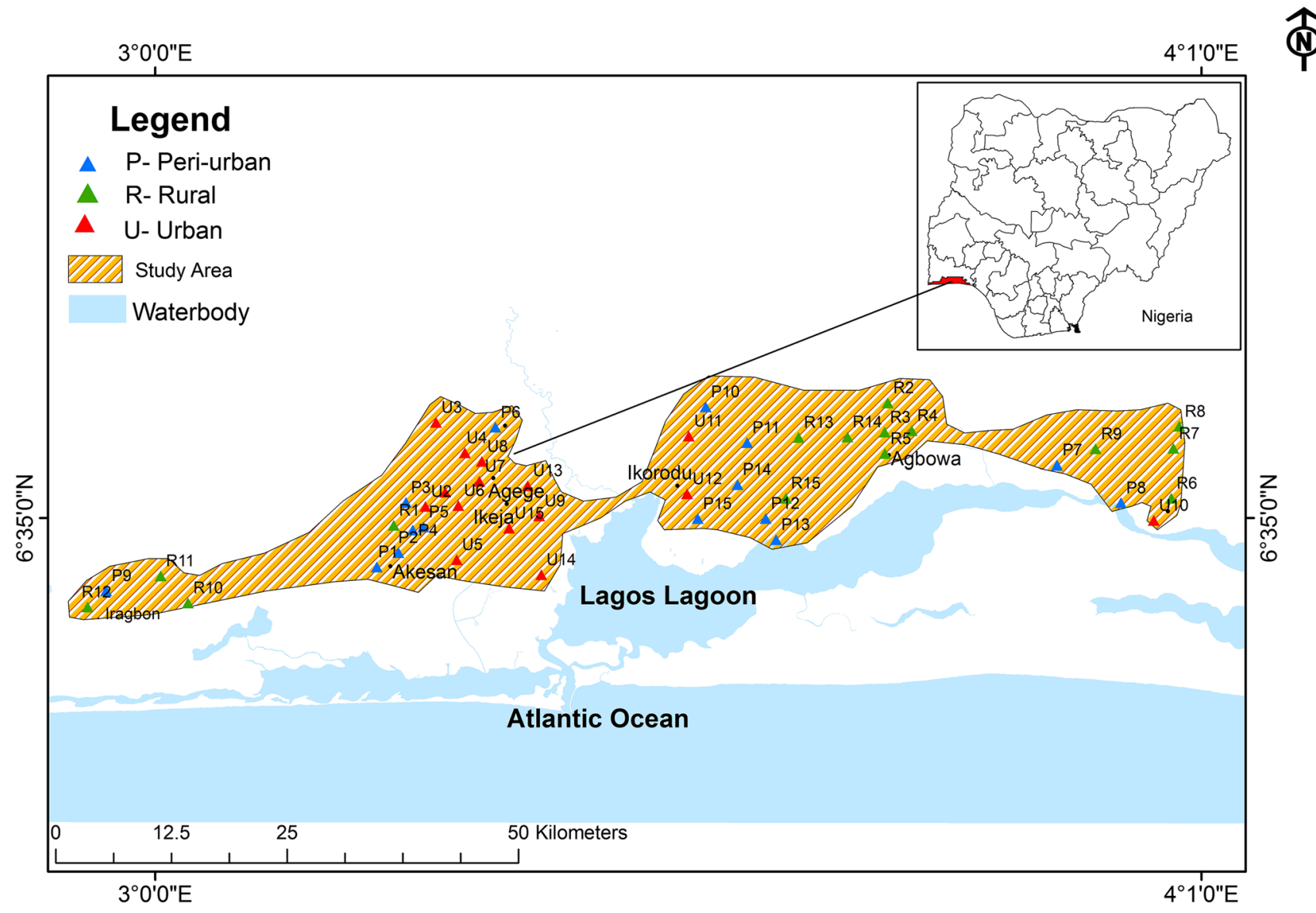

Fig. 2 The sampling sites 
$C B E=\left(\sum\right.$ cations $-\sum$ anions $) /\left(\sum\right.$ cations $+\sum$ anions $) \times 100 \%$

Descriptive, inferential, and multivariate statistical techniques were employed for data analyses using Statistical Package for Social Sciences (SPSS) 22.0 version.

\section{Water quality indices}

\section{Drinking water quality index}

The WQI of the study area was computed using 11 parameters, namely $\mathrm{pH}$, TDS, $\mathrm{EC}, \mathrm{Ca}^{2+}, \mathrm{Mg}^{2+}, \mathrm{TH}, \mathrm{Na}^{+}, \mathrm{K}^{+}, \mathrm{Cl}^{-}, \mathrm{HCO}_{3}{ }^{-}$, and $\mathrm{SO}_{4}{ }^{2-}$, to determine the suitability of the water for human consumption using the method proposed by Sahu and Sikdar (2008). The computation involved four stages as follows:

1. Allocation of weight to each parameter according to their relative importance in line with WHO (2011) guideline for drinking purpose (Table 1)

2. Computation of relative weight (Wi) based on Eq. 3 .

$W i=w i / \sum_{i}^{n}=1 w i$

where $W i=$ relative weight, $w i=$ weight of each parameter, and $n=$ number of parameters.

3. Allocation of quality rating scale (qi) for each parameter (Eq. 4).

$q i=\left(\frac{C i}{S i}\right) \times 100$

Table 1 Relative weight of groundwater parameters

\begin{tabular}{llll}
\hline Parameter & $\begin{array}{l}\text { WHO guide- } \\
\text { line (2011) }\end{array}$ & Weight (wi) & Relative weight (Wi) \\
\hline $\mathrm{pH}$ & $6.5-8.5$ & 4 & 0.11 \\
$\mathrm{TDS}$ & $500 \mathrm{mg} / \mathrm{L}$ & 5 & 0.14 \\
$\mathrm{EC} \mu \mathrm{S} / \mathrm{cm}$ & $500 \mathrm{mg} / \mathrm{L}$ & 4 & 0.11 \\
$\mathrm{Ca}^{2+}$ & $75 \mathrm{mg} / \mathrm{L}$ & 2 & 0.06 \\
$\mathrm{Mg}^{2+}$ & $30 \mathrm{mg} / \mathrm{L}$ & 2 & 0.06 \\
$\mathrm{TH}^{+}$ & $200 \mathrm{mg} / \mathrm{L}$ & 2 & 0.06 \\
$\mathrm{Na}^{+}$ & $200 \mathrm{mg} / \mathrm{L}$ & 4 & 0.11 \\
$\mathrm{~K}^{+}$ & $200 \mathrm{mg} / \mathrm{L}$ & 2 & 0.06 \\
$\mathrm{Cl}^{-}$ & $250 \mathrm{mg} / \mathrm{L}$ & 3 & 0.09 \\
$\mathrm{HCO}_{3}^{-}$ & $500 \mathrm{mg} / \mathrm{L}$ & 3 & 0.09 \\
$\mathrm{SO}_{4}{ }^{-}$ & $250 \mathrm{mg} / \mathrm{L}$ & 4 & 0.11 \\
& & $\sum w i=35$ & $\sum W i=1.00$ \\
\hline
\end{tabular}

where $q i=$ quality rating, $C i=$ concentration of each parameter, and $\mathrm{Si}=\mathrm{WHO}$ (2011) drinking water guideline for each parameter.

4. The final WQI is calculated based on Eqs. 5 and 6 .

$$
\begin{aligned}
& S I i=W i \times q i \\
& W Q I=\sum_{i=1}^{n} S I i
\end{aligned}
$$

where $S I i$ is the sub-index of $i$ th parameter, while $q i$ is the rating according to the concentration of $i$ th parameter, and $n$ is number of parameters. The computed WQI values are classified into five categories according to Sahu and Sikdar (2008) as follows:

$<50 \quad$ Excellent water

50-100 Good water

100-200 Poor water

200-300 Very poor water

$>300 \quad$ Water unfit for drinking

\section{Groundwater salinization}

The degree of groundwater salinization was determined using Revelle index (RI) (Revelle 1941) as indicated in Eq. 7.

$\mathrm{RI}=\mathrm{rCl}^{-} /\left(\mathrm{rHCO}_{3}^{-}+\mathrm{rCO}_{3}^{-}\right)$

where $r=$ meq/L, $\mathrm{Cl}$-chloride, $\mathrm{HCO}_{3}{ }^{-}$-bicarbonate, $\mathrm{CO}_{3}{ }^{-}$- carbonate.

The computed RI values are classified into three categories according to Revelle (1941) as follows:

$<0.5 \mathrm{meq} / \mathrm{L} \quad$ unaffected

0.5-6.6 meq/L slightly affected

$>6.6 \mathrm{meq} / \mathrm{L} \quad$ strongly affected

\section{Water stability index}

The prediction of the tendency of scaling or corrosion of water was determined based on Langelier saturation index (LSI) proposed by Langelier and Ludwig (1942) and Gupta et al. (2011) using AquaChem software 2012.1 version. The LSI is defined using Eq. 8.

$L S I=p H-p H s$

where $\mathrm{pH}=$ measured water $\mathrm{pH}$ and $\mathrm{pHs}=\mathrm{pH}$ at saturation in calcite or calcium carbonate and is calculated using Eq. 9.

$\mathrm{pHs}=(9.3+A+B)-(C+D)$

where notations A to D are obtained using Eqs. 10 to 13. 
$A=(\log 10[T D S]-1) / 10$

$B=-13.12 \times \log 10(0 C+273)+34.55$

$C=\log 10[\mathrm{CaH}$ as $\mathrm{CaCO} 3]-0.4$

$D=\log 10$ [total alkalinity as $\mathrm{CaCO} 3]$

The LSI values are classified into eleven categories according to Langelier and Ludwig (1942) as follows:

\begin{tabular}{lll}
\hline 1 & -4.0 & Very severe corrosion \\
2 & -3.0 & Severe corrosion \\
3 & -2.0 & Moderate corrosion \\
4 & -1.0 & Mild corrosion \\
5 & -0.5 & Slight corrosion \\
6 & 0.0 & Balanced \\
7 & 0.5 & Faint scale coating \\
8 & 1.0 & Slight scale/ encrustation \\
9 & 2.0 & Mild scale/encrustation \\
10 & 3.0 & Moderate scale/encrustation \\
11 & 4.0 & Severe scale/encrustation \\
\hline
\end{tabular}

\section{Graphical techniques of water quality assessment}

\section{Gibbs plot}

Gibbs ratio (GR) was employed to determine the dominant mechanism controlling groundwater chemistry and the sources of dissolved ions to understand the interaction between rock and water (Gibbs 1970). GR - 1 was used to plot the anions $\left(\mathrm{Cl}^{-} / \mathrm{Cl}^{-}+\mathrm{HCO}_{3}^{-}\right)$, while GR-II was employed for the cations $\left(\mathrm{Na}^{+}+\mathrm{K}^{+} /\left(\mathrm{Na}^{+}+\mathrm{K}^{+}+\mathrm{Ca}^{2+}\right)\right.$ as a function of TDS. See Eqs. 14 and 15.
Gibb Ratio $\mathrm{I}=\mathrm{Cl} /(\mathrm{Cl}+\mathrm{HCO} 3)$

Gibb Ratio II $=(\mathrm{Na}+\mathrm{K}) /(\mathrm{Na}+\mathrm{K}+\mathrm{Ca})$

\section{Piper's plot}

The hydrochemical facies of the groundwater were characterized based on the classification scheme for the subdivisions of Piper's diagram suggested by Back and Hanshaw (1965) (See Fig. 3). The facies were plotted using Rockware Aq.QA software version 1.1.1[1.1.5.1] 2006 edition.

\section{Results and discussion}

\section{Physicochemical parameters of groundwater}

The physicochemical parameters of groundwater of the three geographical settlements during the dry season are presented in Table 2. The groundwater $\mathrm{pH}$ in the peri-urban varied between 3.13 and 7.3 indicating acidic to a slightly alkaline condition. The observed low $\mathrm{pH}$ in groundwater of the study area may be linked to dissolved carbon dioxide or increase in groundwater temperature (Robinson et al. 2009). The groundwater parameters in all the sites show a low to moderate variation except at Igando with EC, TDS, $\mathrm{Mg}^{2+}$, $\mathrm{Na}^{+}, \mathrm{Cl}^{-}, \mathrm{HCO}_{3}{ }^{-}$, and $\mathrm{SO}_{4}{ }^{2-}$ in the peri-urban. High sulfate recorded in groundwater can be attributed to leaching from municipal waste and sewage water pollutants (Singh 1994). The dominant cation is $\mathrm{Na}^{+}$, and the concentration ranged between 1.9 and $1350 \mathrm{mg} / \mathrm{L}$ while $\mathrm{Cl}^{-}$is the dominant anion and ranged between 4 and 2, $800 \mathrm{mg} / \mathrm{L}$. The high values of these parameters at Igando can be attributed to infiltration of leachates from the dump sites in the area. In the
Fig. 3 Classification of hydrochemical facies

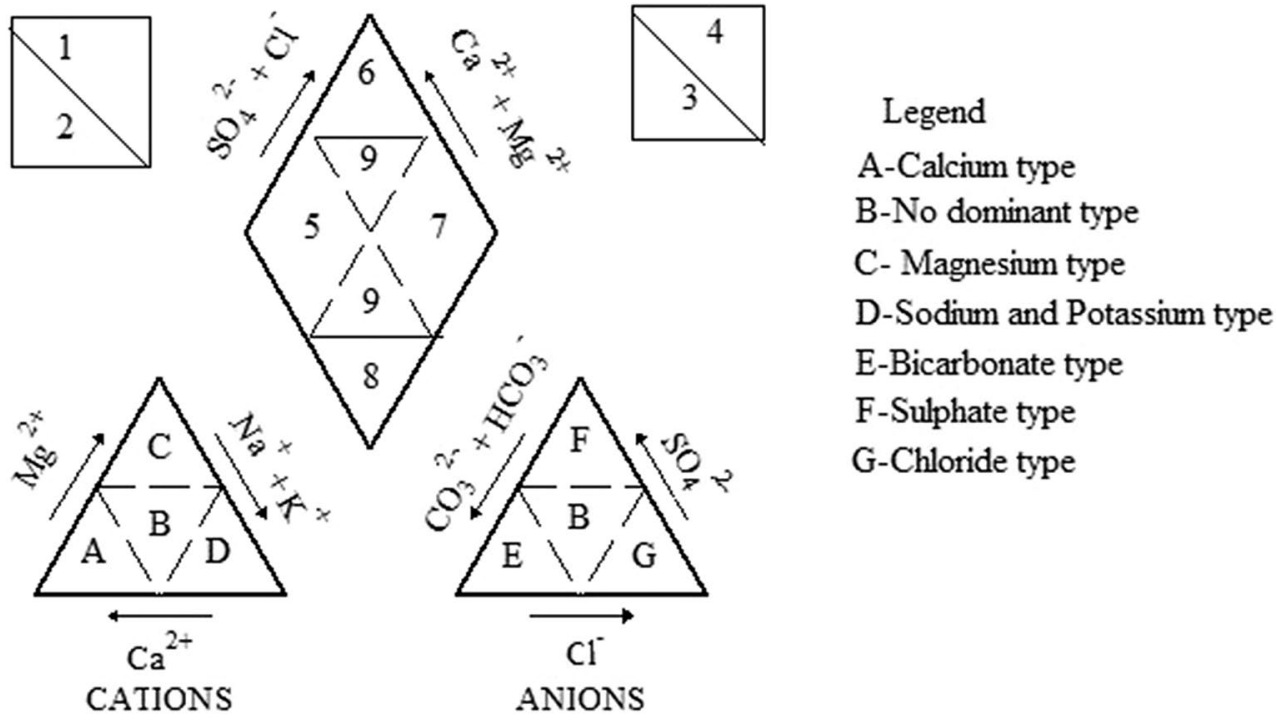


Table 2 Physicochemical parameters of groundwater in the dry season

\begin{tabular}{|c|c|c|c|c|c|c|c|c|c|c|c|c|}
\hline Sample code & Site & $\mathrm{pH}$ & $\mathrm{EC}$ & TDS & $\mathrm{Ca}^{2+}$ & $\mathrm{Mg}^{2+}$ & $\mathrm{Na}^{+}$ & $\mathrm{K}^{+}$ & $\mathrm{Cl}^{-}$ & $\mathrm{HCO}_{3}^{-}$ & $\mathrm{SO}_{4}{ }^{2-}$ & $\mathrm{CO}_{3}^{-}$ \\
\hline \multicolumn{13}{|c|}{ Peri-urban settlement } \\
\hline $\mathrm{P} 1$ & Obadore & 5.14 & 58 & 42 & 8 & 2 & 5.11 & 1.35 & 18 & 78.4 & 3 & ND \\
\hline $\mathrm{P} 2$ & Egan & 5.95 & 135 & 90 & 52 & 24 & 4.98 & 1.07 & 18 & 178.8 & 5 & ND \\
\hline $\mathrm{P} 3$ & Ayobo & 5.14 & 39 & 28 & 16 & 4 & 3.72 & 0.86 & 16 & 96.2 & 3 & ND \\
\hline P4 & Igando & 7.3 & 9778 & 4890 & 52 & 222 & 1350 & 5.62 & 2800 & 286.6 & 82 & ND \\
\hline P5 & Ogbomoso & 5.32 & 124 & 85 & 41 & 11 & 5.88 & 1.53 & 22 & 57.9 & 5 & ND \\
\hline P6 & Iju & 4.55 & 73 & 55 & 16 & 4 & 6.95 & 1.35 & 22 & 20 & 3 & ND \\
\hline P7 & Ketu & 3.13 & 117 & 82 & 20 & 4 & 2.59 & 0.52 & 8 & 30 & 3 & ND \\
\hline P8 & Temu & 5.22 & 13 & 10 & 10 & ND & 7.97 & 1.46 & 28 & 67.8 & 2 & ND \\
\hline P9 & Ikoga-Zebbe & 4.86 & 17 & 12 & 0.77 & 0.26 & 1.87 & 0 & 4 & 66 & 6 & ND \\
\hline P10 & Odo-Kekere & 5.54 & 33 & 23 & 25 & 9 & 6.98 & 1.48 & 12 & 170 & 3 & ND \\
\hline P11 & Maya & 5.73 & 23 & 17 & 17 & 5 & 5.62 & 1.86 & 10 & 110 & 2 & ND \\
\hline $\mathrm{P} 12$ & Ijede & 5.67 & 91 & 69 & 32 & 6 & 4.04 & 1.44 & 12 & 80 & 4 & ND \\
\hline P13 & Egbin & 4.73 & 158 & 112 & 41 & 11 & 9.49 & 2.11 & 36 & 127.6 & 6 & ND \\
\hline P14 & Elepe & 5.9 & 22 & 23 & 12 & 6 & 3.88 & 0.73 & 12 & 138 & 2 & ND \\
\hline P15 & Selewu & 5.32 & 27 & 20 & 11 & 7 & 3.72 & 0.77 & 12 & 120 & 2 & ND \\
\hline \multicolumn{13}{|c|}{ Rural settlement } \\
\hline $\mathrm{R} 1$ & Kaka & 5.37 & 38 & 27 & 13 & 5 & 4.26 & 0.9 & 16 & 115.2 & 3 & ND \\
\hline R2 & Abatiwa & 5.62 & 39 & 27 & 18 & 6 & 5.04 & 1.82 & 16 & 90 & 2 & ND \\
\hline R3 & Odo-Onosa & 5.21 & 113 & 79 & 74 & 26 & 4.59 & 1.22 & 14 & 159.8 & 3 & ND \\
\hline R4 & Ota-Ikosi & 3.9 & 18 & 13 & 13 & 3 & 3.98 & 1.02 & 12 & 140 & 2 & ND \\
\hline R5 & Agbowa & 6.18 & 172 & 115 & 90 & 36 & 2.86 & 0.54 & 8 & 10 & 4 & ND \\
\hline R6 & Odo-Mola & 4.83 & 33 & 24 & 4 & 4 & 7.56 & 1.47 & 24 & 40 & 2 & ND \\
\hline R7 & Eredo & 5.24 & 25 & 17 & 2 & 2 & 6.32 & 0.82 & 16 & 20 & 2 & ND \\
\hline R8 & Ibowon & 5.38 & 75 & 57 & 20 & 10 & 2.16 & 0.49 & 6 & 48.2 & 3 & ND \\
\hline R9 & Igbodu & 5.16 & 59 & 43 & 31 & 5 & 5.84 & 1.36 & 20 & 60 & 3 & ND \\
\hline $\mathrm{R} 10$ & Ilogbo & 5.21 & 349 & 226 & 2.8 & 0.58 & 53.37 & 51.69 & 144 & 46 & 4 & ND \\
\hline $\mathrm{R} 11$ & Okoron & 5.92 & 22 & 16 & 1.52 & 0.44 & 2.86 & 4.42 & 10 & 93.3 & 8 & ND \\
\hline $\mathrm{R} 12$ & Iragbon & 4.77 & 48 & 36 & 1.19 & 0.297 & 5.62 & 2.82 & 18 & 66 & 7 & ND \\
\hline $\mathrm{R} 13$ & Isiu & 5.14 & 85 & 63 & 20 & 6 & 5.99 & 1.92 & 20 & 86.4 & 4 & ND \\
\hline $\mathrm{R} 14$ & Imota & 5.01 & 105 & 74 & 19 & 7 & 5.68 & 1.38 & 22 & 79 & 4 & ND \\
\hline $\mathrm{R} 15$ & Gberigbe & 5.88 & 30 & 22 & 21 & 9 & 6.58 & 1.57 & 12 & 120 & 2 & ND \\
\hline \multicolumn{13}{|c|}{ Urban settlement } \\
\hline $\mathrm{U} 1$ & Ipaja & 3.3 & 227 & 154 & 30 & 8 & 13.29 & 2.55 & 40 & 18.6 & 7 & ND \\
\hline $\mathrm{U} 2$ & Baruwa & 5.89 & 135 & 94 & 55 & 15 & 2.96 & 0.62 & 14 & 156 & 6 & ND \\
\hline $\mathrm{U} 3$ & Alagbado & 4.5 & 77 & 57 & 18 & 2 & 6.07 & 1.29 & 28 & 40 & 4 & ND \\
\hline $\mathrm{U} 4$ & Oke-Odo & 4.3 & 27 & 18 & 10 & 4 & 3.02 & 1.05 & 14 & 30 & 2 & ND \\
\hline U5 & Ejigbo & 5.02 & 93 & 64 & 13 & 5 & 7.12 & 2.08 & 22 & 60 & 4 & ND \\
\hline U6 & Egbeda & 4.33 & 119 & 84 & 9 & 3 & 9.86 & 2.29 & 34 & 18.4 & 5 & ND \\
\hline U7 & Dopemu & 5.12 & 409 & 274 & 30 & 8 & 30.21 & 5.81 & 98 & 80 & 9 & ND \\
\hline U8 & Oko-Oba & 4.99 & 598 & 391 & 50 & 10 & 45.3 & 10.27 & 146 & 40 & 8 & ND \\
\hline U9 & Olushosun & 3.02 & 426 & 289 & 61 & 11 & 41.54 & 9.79 & 128.8 & 10 & 9 & ND \\
\hline U10 & Epe & 3.76 & 191 & 129 & 28 & 8 & 13.55 & 2.98 & 44 & 30 & 4 & ND \\
\hline U11 & Odogunyan & 5.7 & 151 & 101 & 50 & 12 & 12.45 & 2.31 & 38 & 114.6 & 5 & ND \\
\hline U12 & Ikorodu & 4.4 & 120 & 88 & 14 & 4 & 4.02 & 0.89 & 36 & 140 & 4 & ND \\
\hline U13 & Alausa & 7.2 & 102 & 53 & 38 & 2 & 3.8 & 0.08 & 12 & 181.5 & 1.2 & ND \\
\hline U14 & Shomolu & 5.95 & 362 & 189 & 36 & 24 & 25.48 & 15.24 & 56 & 42 & 4 & ND \\
\hline U15 & Shogunle & 5.85 & 515 & 261 & 24 & 16 & 21.26 & 10.22 & 52 & 38 & 5 & ND \\
\hline
\end{tabular}

All samples are in $\mathrm{mg} / \mathrm{L}$ except $\mathrm{pH}$ and $\mathrm{EC}\left(\mu \mathrm{S} \mathrm{cm}^{-1}\right)$

$N D$ Not detected 
rural settlement, $\mathrm{pH}$ indicates acidic to moderately alkaline conditions (3.9 to 6.2). The concentration of EC, TDS, $\mathrm{K}^{+}$, and $\mathrm{Cl}^{-}$were relatively high at Ilogbo. These parameters varied between 18 to $349 \mu \mathrm{S} \mathrm{cm}^{-1}, 13$ to $226 \mathrm{mg} / \mathrm{L}, 0.5$ to $51.7 \mathrm{mg} / \mathrm{L}$, and 6 to $144 \mathrm{mg} / \mathrm{L}$, respectively. High TDS may be due to the impact of anthropogenic sources, such as domestic sewage, septic tanks, and agricultural activities (Logeshkumaran et al. 2015). The observed high EC in groundwater may be linked to nutrient enrichment (Srinivasamoorthy et al. 2014). The concentration of $\mathrm{Ca}^{2+}$ and $\mathrm{Mg}^{2+}$ was relatively high at Agbowa with a corresponding range of 1.2 and $90 \mathrm{mg} / \mathrm{L}$ and between 0.3 and $36 \mathrm{mg} / \mathrm{L}$, respectively. The relatively high concentration of $\mathrm{Ca}^{2+}$ and $\mathrm{Mg}^{2+}$ can be linked to the water-rock interaction (Todd and Larry 2005). Sodium, $\mathrm{K}^{+}$, and $\mathrm{Cl}^{-}$were low in all the sites except at Ilogbo. High concentration of these parameters can be attributed to seepage and surface /groundwater interaction with the surrounding lagoon. Sodium ranged between 2.2 and $53.4 \mathrm{mg} / \mathrm{L}$, while bicarbonate varied between 10 to $159.8 \mathrm{mg} / \mathrm{L}$. The predominant cation is $\mathrm{Ca}^{2+}$ with a mean value of $24.8 \mathrm{mg} / \mathrm{L}$, while $\mathrm{HCO}_{3}{ }^{-}$is the dominant anion with an average of $79.0 \mathrm{mg} / \mathrm{L}$. The $\mathrm{pH}$ of groundwater in the urban settlement indicates acidic to slightly alkaline conditions (3.0-7.2). A relatively low variation was observed in all the sites except at Oko-Oba which has a relatively high concentration of EC, TDS, and $\mathrm{Cl}^{-}$with the corresponding mean of $245.7 \mu \mathrm{S} \mathrm{cm}^{-1}, 156.2 \mathrm{mg} / \mathrm{L}$, and $54.2 \mathrm{mg} / \mathrm{L}$, respectively. High chloride in groundwater may result from inadequate underground drainage system and poor management of the environment around the abattoir in the area (Logeshkumaran et al. 2015). The concentration of $\mathrm{HCO}_{3}{ }^{-}$varied between 10 to $181 \mathrm{mg} / \mathrm{L}$ with a mean of $70 \mathrm{mg} / \mathrm{L}$. The dominant cation is $\mathrm{Ca}^{2+}$ with an average of $31.5 \mathrm{mg} / \mathrm{L}$, while $\mathrm{HCO}_{3}{ }^{-}$is the dominant anion.

Table 3 presents the variations of the physicochemical parameters of groundwater during the wet season in the study area. The result revealed that in the peri-urban, EC, TDS, $\mathrm{Na}^{+}, \mathrm{K}^{+}, \mathrm{Cl}^{-}$, and $\mathrm{HCO}_{3}{ }^{-}$were extremely higher at Igando compared to other sites. High bicarbonate in groundwater may result from atmospheric $\mathrm{CO}_{2}$ and $\mathrm{CO}_{2}$ released from the organic decomposition in the soil around the dumpsite (Rao 2002). Electrical conductivity ranged between 15 and $6600 \mu \mathrm{S} \mathrm{cm}^{-1}$, TDS between 13 and $3300 \mathrm{mg} / \mathrm{L}$. Sodium varied between 2 to $1142 \mathrm{mg} / \mathrm{L}$, while potassium ranged between 0.1 and $1102 \mathrm{mg} / \mathrm{L}$. Chloride ranged between 2 and $2280 \mathrm{mg} / \mathrm{L}$, while bicarbonate varied between 14 to $228 \mathrm{mg} / \mathrm{L}$. The groundwater $\mathrm{pH}$ indicates moderately acidic to slightly alkaline (4.6-7.4). The variations of $\mathrm{Ca}^{2+}, \mathrm{Mg}^{2+}, \mathrm{SO}_{4}{ }^{2-}$, and $\mathrm{CO}_{3}{ }^{-}$are low. Sodium and chloride are the dominant cation and anion in the area. There is no significant variation in the groundwater parameters in the rural settlement except for Ilogbo with a relatively high $\mathrm{EC}$, TDS, and $\mathrm{Cl}^{-}$. The $\mathrm{pH}$ is moderately acidic to neutral
(4.8-7.0). The dominant cation is $\mathrm{Na}^{+}$with a mean value of $58.4 \mathrm{mg} / \mathrm{L}$, while $\mathrm{Cl}^{-}$is the dominant anion with an average of $137 \mathrm{mg} / \mathrm{L}$. There are slight variations in the groundwater parameters such as EC, TDS, $\mathrm{Na}^{+}, \mathrm{Cl}^{-}$, and $\mathrm{HCO}_{3}{ }^{-}$in the urban settlement. Electrical conductivity ranged between 26 and $509 \mu \mathrm{S} \mathrm{cm}{ }^{-1}$, TDS between 15 and $332 \mathrm{mg} / \mathrm{L}$. Sodium varied between 4.1 to $119.5 \mathrm{mg} / \mathrm{L}, \mathrm{Cl}^{-}$between 6 to $125 \mathrm{mg} / \mathrm{L}$, and $\mathrm{HCO}_{3}{ }^{-}$between 8 to $139 \mathrm{mg} / \mathrm{L}$. Sodium and bicarbonate are the dominant cation and anion with an average of $41.9 \mathrm{mg} / \mathrm{L}$ and $49.5 \mathrm{mg} / \mathrm{L}$, respectively.

\section{Bivariate analysis of groundwater parameters}

The seasonal variations of the physicochemical parameters of groundwater in the study area show that about $95.6 \%$ and $60 \%$ of the sampling sites had $\mathrm{pH}$ values below the minimum guideline for potable water prescribed by WHO (2011). Similarly, only $2.2 \%$ of the measured EC fall under high enrichments of salts $\left(E C>3000 \mu \mathrm{S} / \mathrm{cm}^{-1}\right.$ ) in both seasons (Rao et al. 2012; Vincy et al. 2015). The classification of TDS revealed that only $2.2 \%$ of the samples are moderately saline in both seasons (Carroll 1962). Total hardness of groundwater shows that approximately 51.1, 28.9, 15.6, and 4.4\% of the samples in the dry season indicate soft, moderately hard, hard, and very hard, respectively, while $93.3 \%$ and $6.97 \%$ represent soft and moderately hard water in the wet season, respectively (Todd and Larry 2005). The distribution of chloride in the study area shows that $2.2 \%$ indicate extremely fresh/brackish-salt in the dry season, while $11.1 \%$ and $2.2 \%$ are extremely fresh and brackish-salt, respectively, in the wet season (Stuyfzand 1989).The distribution of bicarbonate shows that $84.4 \%$ and $66.7 \%$ of the samples fall under poor zone in the wet and dry seasons, respectively (WHO 2011). The result of the seasonal paired sample $T$ test shows significant variations between $\mathrm{pH}, \mathrm{Ca}^{2+}, \mathrm{HCO}_{3}{ }^{-}$, and $\mathrm{Mg}^{2+}$ in the study area (Table 4). The wet season parameters are in asterisk.

\section{Multivariate analysis of groundwater parameters}

The result of the factor analysis (FA) extracted two factors and explained $73.5 \%$ of the total variance in the dry season, while three factors were obtained in the wet season, accounting for $84.2 \%$ of the total variance (Table 5).

Factor I, in the dry season, accounts for $61.8 \%$ of the total variance with high loading on EC, TDS, $\mathrm{Ca}^{2+}, \mathrm{Mg}^{2+}$, $\mathrm{Na}^{+}, \mathrm{Cl}^{-}$, and $\mathrm{SO}_{4}{ }^{2-}$. These parameters represent seawater constituents (Lu et al. 2012). Factor II accounts for $11.6 \%$ of the total variance and is characterized by medium loadings of $\mathrm{Ca}^{2+}, \mathrm{K}^{+}$, and $\mathrm{HCO}_{3}{ }^{-}$(Table 5). In the wet season, factor I accounts for $59.4 \%$ of the total variance, with high loadings on $\mathrm{EC}$, TDS, $\mathrm{Na}^{+}, \mathrm{K}^{+}, \mathrm{Cl}^{-}$, and $\mathrm{SO}_{4}{ }^{2-}$. The high loading on $\mathrm{Cl}^{-}$may be attributed to saltwater intrusion, 
Table 3 Physicochemical parameters of groundwater in the wet season

\begin{tabular}{|c|c|c|c|c|c|c|c|c|c|c|c|c|}
\hline Sample code & Site & PH & EC & TDS & $\mathrm{Ca}^{2+}$ & $\mathrm{Mg}^{2+}$ & $\mathrm{Na}^{+}$ & $\mathrm{K}^{+}$ & $\mathrm{Cl}^{-}$ & $\mathrm{HCO}_{3}^{-}$ & $\mathrm{SO}_{4}^{2-}$ & $\mathrm{CO}_{3}^{-}$ \\
\hline \multicolumn{13}{|c|}{ Peri-urban settlement } \\
\hline $\mathrm{P} 1$ & Obadore & 5.8 & 64 & 44 & 1.71 & 0.1 & 24.3 & 0.27 & 20 & 60 & 3 & 0.01 \\
\hline $\mathrm{P} 2$ & Egan & 6.5 & 102 & 69 & 17.4 & 0.44 & 17.12 & 1.05 & 4 & 80 & 4 & 0.01 \\
\hline P3 & Ayobo & 6.1 & 129 & 89 & 4.18 & 1.62 & 53.48 & 0.22 & 108 & 49 & 6 & 0.01 \\
\hline P4 & Igando & 6.3 & 6600 & 3300 & 4.84 & 1.95 & 1142 & 1102 & 2250 & 228 & 46 & 0.1 \\
\hline P5 & Ogbomoso & 6.1 & 116 & 79 & 28.3 & 0.39 & 13.57 & 1.39 & 16 & 42 & 4 & 0.03 \\
\hline P6 & Iju & 5.8 & 70 & 48 & 4.8 & 4.74 & 2.89 & 0.98 & 7 & 14 & 2 & 0.04 \\
\hline P7 & Ketu & 4.6 & 123 & 87 & 12.4 & 0.14 & 3.17 & 0.47 & 4 & 26 & 2 & 0 \\
\hline P8 & Temu & 6.8 & 15 & 19 & 6.24 & 0.06 & 8.05 & 1.42 & 21 & 55 & 2 & 0.01 \\
\hline P9 & Ikoga-Zebbe & 4.9 & 21 & 14 & 0.73 & 0.21 & 1.96 & 0.08 & 2 & 31 & 5 & 0.02 \\
\hline P10 & Odo-Kekere & 6.5 & 29 & 21 & 6.68 & 0.04 & 12.86 & 1.94 & 7 & 138 & 2 & 0.06 \\
\hline P11 & Maya & 6.2 & 19 & 13 & 1.68 & 0.07 & 5.36 & 0.24 & 10 & 85 & 2 & 0.01 \\
\hline P12 & Ijede & 7.4 & 111 & 77 & 14.9 & 0.92 & 32.77 & 4.77 & 10 & 72 & 5 & 0.01 \\
\hline P13 & Egbin & 6.6 & 152 & 99 & 16.6 & 1.46 & 35.57 & 5.76 & 29 & 105 & 5 & 0.08 \\
\hline P14 & Elepe & 6.5 & 36 & 25 & 4.31 & 0.09 & 9.38 & 0.47 & 12 & 100 & 3 & 0.03 \\
\hline P15 & Selewu & 6.7 & 23 & 14 & 4.7 & 0.32 & 3.78 & 0.82 & 8 & 94 & 2 & 0.01 \\
\hline \multicolumn{13}{|c|}{ Rural settlement } \\
\hline $\mathrm{R} 1$ & Kaka & 6.4 & 34 & 22 & 3.24 & 2.4 & 5.23 & 0.4 & 4 & 90 & 5 & 0.01 \\
\hline $\mathrm{R} 2$ & Abatiwa & 6.6 & 26 & 18 & 2.72 & 0.07 & 8.29 & 0.15 & 14 & 80 & 2 & 0.01 \\
\hline R3 & Odo-Onosa & 6.5 & 103 & 70 & 14.3 & 0.79 & 9.18 & 10.57 & 16 & 62 & 4 & 0.08 \\
\hline $\mathrm{R} 4$ & Ota-Ikosi & 5.5 & 15 & 11 & 5.28 & 0.2 & 3.4 & 0.8 & 6 & 57 & 2 & 0.01 \\
\hline R5 & Agbowa & 6.7 & 167 & 106 & 40.1 & 0.91 & 18.15 & 6.98 & 5 & 15 & 5 & 0.04 \\
\hline R6 & Odo-Mola & 5.3 & 35 & 38 & 0.4 & 1.04 & 7.8 & 1.33 & 18 & 37 & 2 & 0.1 \\
\hline R7 & Eredo & 6.2 & 29 & 18 & 0.08 & 0.09 & 6.91 & 0.81 & 12 & 18 & 2 & 0.01 \\
\hline R8 & Ibowon & 6.7 & 87 & 62 & 10.5 & 1.07 & 2.7 & 0.29 & 4 & 40 & 3 & 0.04 \\
\hline R9 & Igbodu & 6.1 & 72 & 48 & 14.6 & 1.3 & 5.83 & 1.33 & 12 & 70 & 2 & 0.02 \\
\hline $\mathrm{R} 10$ & Ilogbo & 5.6 & 358 & 231 & 2.6 & 0.44 & 58.4 & 49.42 & 137 & 37 & 3 & 0.01 \\
\hline R11 & Okoron & 6 & 26 & 19 & 1.42 & 0.38 & 3.1 & 3.68 & 8 & 75 & 6 & 0.01 \\
\hline $\mathrm{R} 12$ & Iragbon & 4.8 & 52 & 42 & 0.59 & 0.18 & 5.84 & 2.14 & 15 & 34 & 6 & 0.06 \\
\hline $\mathrm{R} 13$ & Isiu & 6.7 & 84 & 58 & 5.56 & 0.65 & 18.87 & 1.03 & 16 & 55 & 4 & 0.01 \\
\hline R14 & Imota & 6.7 & 110 & 76 & 17.1 & 0.45 & 23.98 & 2.46 & 14 & 68 & 5 & 0.01 \\
\hline $\mathrm{R} 15$ & Gberigbe & 7 & 31 & 22 & 7.08 & 0.11 & 3.91 & 0.47 & 12 & 104 & 3 & 0.03 \\
\hline \multicolumn{13}{|c|}{ Urban settlement } \\
\hline U1 & Ipaja & 4.4 & 243 & 162 & 3.31 & 0.53 & 82.36 & 3.09 & 54 & 15 & 6 & 0 \\
\hline $\mathrm{U} 2$ & Baruwa & 5.8 & 106 & 73 & 27.2 & 0.35 & 5.36 & 1.57 & 8 & 139 & 4 & 0.02 \\
\hline U3 & Alagbado & 5.8 & 65 & 53 & 3.8 & 0.7 & 8.67 & 0.6 & 9 & 52 & 3 & 0.02 \\
\hline U4 & Oke-Odo & 5.5 & 26 & 15 & 1.82 & 0.59 & 5.44 & 0.3 & 6 & 20 & 2 & 0.03 \\
\hline U5 & Ejigbo & 5.1 & 229 & 148 & 14.3 & 1.34 & 58.24 & 4.16 & 42 & 25 & 5 & 0.01 \\
\hline U6 & Egbeda & 5.6 & 157 & 102 & 4.92 & 0.43 & 55.39 & 2.76 & 38 & 12 & 5 & 0.01 \\
\hline U7 & Dopemu & 5.2 & 423 & 275 & 13.2 & 0.76 & 119.5 & 7.36 & 106 & 30 & 8 & 0.02 \\
\hline U8 & Oko-Oba & 5.2 & 505 & 332 & 43.1 & 1.58 & 109.9 & 22.22 & 125 & 15 & 6 & 0.01 \\
\hline U9 & Olushosun & 3.6 & 438 & 296 & 32.6 & 6.8 & 30.64 & 8.4 & 102 & 8 & 8 & 0.06 \\
\hline U10 & Epe & 4.1 & 176 & 158 & 13.8 & 0.84 & 13.87 & 2.53 & 31 & 23 & 3 & 0.01 \\
\hline U11 & Odogunyan & 6.7 & 149 & 100 & 11 & 0.72 & 38.62 & 4.89 & 38 & 82 & 5 & 0.01 \\
\hline U12 & Ikorodu & 6.4 & 117 & 79 & 5.36 & 0.26 & 4.4 & 1.2 & 24 & 128 & 3 & 0.01 \\
\hline U13 & Alausa & 7.1 & 98 & 43 & 9.24 & 0.08 & 4.1 & 0.42 & 10 & 68 & 1 & 0.01 \\
\hline U14 & Shomolu & 6.8 & 356 & 174 & 11.6 & 4.6 & 27.64 & 14.8 & 43 & 35 & 3 & 0.02 \\
\hline U15 & Shogunle & 6.6 & 509 & 247 & 10.8 & 2.8 & 23.8 & 10.26 & 37 & 43 & 3 & 0.01 \\
\hline
\end{tabular}


Table 4 Seasonal paired samples $T$ test of groundwater parameters

\begin{tabular}{|c|c|c|c|c|c|c|c|c|c|}
\hline \multicolumn{2}{|c|}{ Parameters } & \multirow[t]{2}{*}{ Mean } & \multirow[t]{2}{*}{ SD } & \multirow[t]{2}{*}{ Std. error mean } & \multicolumn{2}{|c|}{$\begin{array}{l}95 \% \text { confidence } \\
\text { interval }\end{array}$} & \multirow[t]{2}{*}{$t$} & \multirow[t]{2}{*}{$D f$} & \multirow[t]{2}{*}{$p$-value } \\
\hline & & & & & Lower & Upper & & & \\
\hline Pair 1 & $\mathrm{pH}-\mathrm{pH}^{*}$ & -0.84 & 0.6 & 0.1 & -1.01 & -0.7 & -8.9 & 44 & 0 \\
\hline Pair 2 & $\mathrm{EC}-\mathrm{EC}^{*}$ & 67.4 & 475.2 & 70.8 & -75.33 & 210.2 & 0.9 & 44 & 0.3 \\
\hline Pair 3 & TDS-TDS* & 34.4 & 238.0 & 35.5 & -37.14 & 105.9 & 0.9 & 44 & 0.3 \\
\hline Pair 4 & $\mathrm{Ca}^{2+}-\mathrm{Ca}^{2+*}$ & 15.3 & 13.9 & 2.01 & 11.14 & 19.5 & 7.4 & 44 & 0 \\
\hline Pair 5 & $\mathrm{Mg}^{2+}-\mathrm{Mg}^{2+*}$ & 11.6 & 32.6 & 4.9 & 1.82 & 21.4 & 2.4 & 44 & 0.0 \\
\hline Pair 6 & $\mathrm{Na}^{+}-\mathrm{Na}^{+*}$ & -7.8 & 39.5 & 5.9 & -19.64 & 4.1 & -1.3 & 44 & 0.2 \\
\hline Pair 7 & $\mathrm{~K}^{+}-\mathrm{K}^{+*}$ & -25.0 & 163.4 & 24.4 & -74.08 & 24.1 & -1.0 & 44 & 0.3 \\
\hline Pair 8 & $\mathrm{Cl}^{-}-\mathrm{Cl}^{-*}$ & 15.0 & 83.2 & 12.4 & -9.97 & 40.1 & 1.2 & 44 & 0.2 \\
\hline Pair 9 & $\mathrm{HCO}_{3}{ }^{--} \mathrm{HCO}_{3}{ }^{-*}$ & 24.1 & 28.2 & 4.2 & 15.62 & 32.6 & 5.7 & 44 & 0 \\
\hline Pair 10 & $\mathrm{SO}_{4}{ }^{2-}-\mathrm{SO}_{4}{ }^{2-*}$ & 1.1 & 5.4 & 0.8 & -0.54 & 2.7 & 1.4 & 44 & 0.2 \\
\hline
\end{tabular}

Table 5 Factor analysis matrix in the dry and wet seasons

\begin{tabular}{|c|c|c|c|c|c|c|}
\hline \multirow[t]{2}{*}{ Parameters } & \multicolumn{2}{|c|}{ Dry season factors } & \multirow[t]{2}{*}{ Parameters } & \multicolumn{3}{|c|}{ Wet season factors } \\
\hline & $F_{1}$ & $F_{2}$ & & $F_{1}$ & $F_{2}$ & $F_{3}$ \\
\hline $\mathrm{pH}$ & 0.4 & 0.3 & $\mathrm{pH}$ & -0.1 & 0.9 & -0.1 \\
\hline EC & 0.9 & 0.0 & $\mathrm{EC}$ & 0.9 & 0.1 & 0.1 \\
\hline TDS & 0.9 & 0.0 & TDS & 0.9 & 0.0 & 0.1 \\
\hline $\mathrm{Ca}^{2+}$ & 0.2 & 0.6 & $\mathrm{Ca}^{2+}$ & -0.1 & 0.0 & 0.8 \\
\hline $\mathrm{Mg}^{2+}$ & 0.9 & 0.2 & $\mathrm{Mg}^{2+}$ & 0.2 & -0.3 & 0.7 \\
\hline $\mathrm{Na}^{+}$ & 0.9 & 0.0 & $\mathrm{Na}^{+}$ & 0.9 & 0.1 & 0.0 \\
\hline $\mathrm{K}^{+}$ & 0.1 & -0.6 & $\mathrm{~K}^{+}$ & 0.9 & 0.1 & 0.0 \\
\hline $\mathrm{Cl}^{-}$ & 0.9 & 0.0 & $\mathrm{Cl}^{-}$ & 0.9 & 0.1 & 0.0 \\
\hline $\mathrm{HCO}_{3}^{-}$ & -0.0 & 0.6 & $\mathrm{HCO}_{3}^{-}$ & 0.6 & 0.7 & -0.2 \\
\hline $\mathrm{SO}_{4}^{2-}$ & 0.9 & 0.0 & $\mathrm{SO}_{4}^{2-}$ & 0.9 & 0.0 & 0.1 \\
\hline $\mathrm{CO}_{3}^{-}$ & ND & ND & $\mathrm{CO}_{3}^{-}$ & 0.5 & 0.1 & 0.4 \\
\hline$\%$ of variance & 61.8 & 11.6 & $\%$ of variance & 59.4 & 15.6 & 9.3 \\
\hline Cumulative \% & 61.8 & 73.5 & Cumulative $\%$ & 59.4 & 74.9 & 84.2 \\
\hline
\end{tabular}

$N D$ Not detected pollutions from sewage, and industrial wastewater (Amadi et al. 2012). Similarly, high loading on $\mathrm{Ca}^{2+}$ indicates the impact of weathering of minerals such as calcite and feldspar on the aquifer system (Sahu et al. 2016). High loading of EC, TDS, $\mathrm{Na}^{+}$, and $\mathrm{SO}_{4}{ }^{2-}$ indicates the influence of salinity on the groundwater system (Abdel Latif and El Kashouty 2010; Lu et al. 2012; Raju et al. 2015). Factor II accounts for $15.6 \%$ of the total variance and is characterized by high to medium loading of $\mathrm{pH}$ and $\mathrm{HCO}_{3}{ }^{-}$. Factor III accounts for $9.3 \%$ of the total variance with high and medium positive loading on $\mathrm{Ca}^{2+}$ and $\mathrm{Mg}^{2+}$, respectively. The constituents of EC and TDS can be categorized as an anthropogenic source of pollution from leachates, sewage, and wastewater in the area ( $\mathrm{Lu}$ et al. 2012). The extreme values of EC and TDS from Igando $\left(\mathrm{P}_{4}\right)$, a sample site near a dumpsite, are very conspicuous.

\section{Mechanism controlling groundwater}

The Gibb's plot revealed the dominance of rock-weathering as the major mechanism controlling groundwater chemistry and the sources of dissolved ions in the study area (Gibbs 1970). The results show that more than $95 \%$ and $93 \%$ of the anions and cations are dominated by rock-weathering in both seasons (Figs. 4 and 5). Studies by Logeshkumaran et al. (2015) confirm the predominance of the rock-water interaction dominance and evaporation in Chennai based on the Gibbs plot. Narany et al. (2014) indicated that the hydrochemistry of Amol-Babol Plain is influenced by rock dominance, carbonate and silicate rock weathering. The findings of Sahu et al. (2016) show that the enrichment of the major ions in the groundwater of West Bengal is due to rock-weathering. Yidana et al. (2012) and Prasanna et al. (2008) reported the dominance of water-rock interaction as the major factors contributing to solute in the study area. 


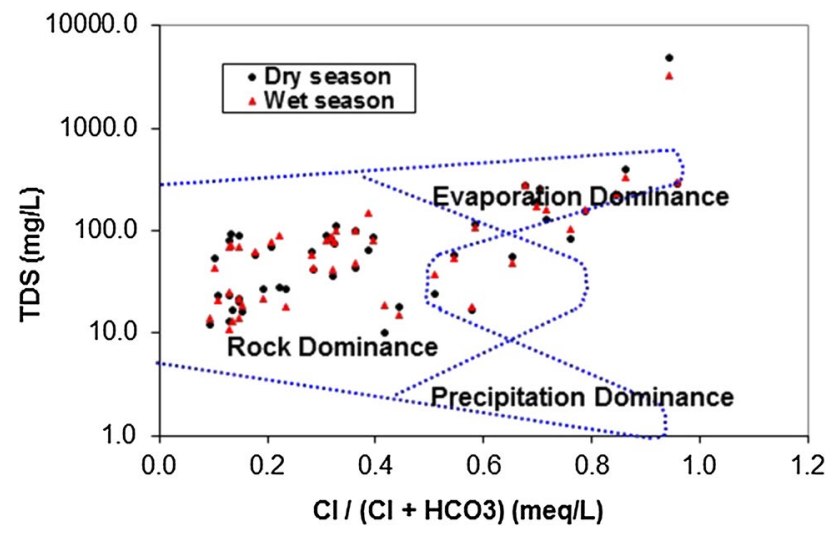

Fig. 4 Gibbs plot of anion

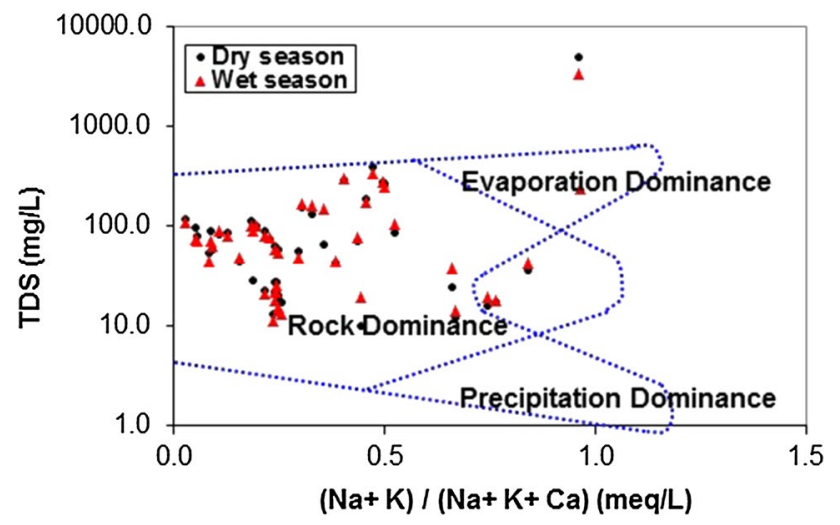

Fig. 5 Gibbs plot of cation

\section{Water quality index}

\section{Drinking water quality}

The results of the drinking WQI show a broad range between 10 and 573 in the peri-urban. The range is relatively low between 10 and 35 and between 11 and 47, respectively, in the rural and urban settlements during the dry season. The wet season value in peri-urban ranged between 9 and 430, while it varies from 10 to 32 and from 9 to 44 in the rural and urban settlements, respectively. Approximately $95.6 \%$ and $2.2 \%$ of the sampling sites have excellent/good water quality, while the remaining $2.2 \%$ indicates unsuitable water for drinking in the peri-urban settlement during the dry season (Table 6). The computed WQI shows that in the wet season, all the sampling sites have excellent quality except at Igando, a peri-urban settlement indicating unsuitable water for drinking (Table 6). The result of the drinking WQI revealed that the rural settlement has the lowest range in both seasons. This can be attributed to the low level of anthropogenic activities that are capable of degrading
Table 6 Water quality index and classification in the study area

\begin{tabular}{|c|c|c|c|c|c|}
\hline \multirow[t]{2}{*}{ Sample code } & \multirow[t]{2}{*}{ Site } & \multicolumn{2}{|c|}{ WQI dry season } & \multicolumn{2}{|c|}{ WQI wet season } \\
\hline & & \multicolumn{2}{|c|}{ Classification } & \multicolumn{2}{|c|}{ Classification } \\
\hline \multicolumn{6}{|c|}{ Peri-urban settlement } \\
\hline $\mathrm{P} 1$ & Obadore & 14 & Excellent & 14 & Excellent \\
\hline $\mathrm{P} 2$ & Egan & 33 & Excellent & 18 & Excellent \\
\hline P3 & Ayobo & 15 & Excellent & 22 & Excellent \\
\hline P4 & Igando & 573 & Unsuitable & 430 & Unsuitable \\
\hline P5 & Ogbomoso & 51 & Good & 18 & Excellent \\
\hline P6 & Iju & 16 & Excellent & 13 & Excellent \\
\hline P7 & Ketu & 16 & Excellent & 15 & Excellent \\
\hline P8 & Temu & 17 & Excellent & 15 & Excellent \\
\hline P9 & Ikoga-Zebbe & 10 & Excellent & 9 & Excellent \\
\hline $\mathrm{P} 10$ & Odo-Kekere & 18 & Excellent & 14 & Excellent \\
\hline P11 & Maya & 15 & Excellent & 12 & Excellent \\
\hline P12 & Ijede & 18 & Excellent & 20 & Excellent \\
\hline P13 & Egbin & 25 & Excellent & 23 & Excellent \\
\hline P14 & Elepe & 19 & Excellent & 17 & Excellent \\
\hline P15 & Selewu & 15 & Excellent & 13 & Excellent \\
\hline \multicolumn{6}{|c|}{ Rural settlement } \\
\hline R1 & Kaka & 19 & Excellent & 16 & Excellent \\
\hline R2 & Abatiwa & 16 & Excellent & 13 & Excellent \\
\hline R3 & Odo-Onosa & 35 & Excellent & 18 & Excellent \\
\hline R4 & Ota-Ikosi & 12 & Excellent & 10 & Excellent \\
\hline R5 & Agbowa & 41 & Excellent & 24 & Excellent \\
\hline R6 & Odo-Mola & 13 & Excellent & 12 & Excellent \\
\hline R7 & Eredo & 10 & Excellent & 11 & Excellent \\
\hline R8 & Ibowon & 18 & Excellent & 16 & Excellent \\
\hline R9 & Igbodu & 16 & Excellent & 15 & Excellent \\
\hline $\mathrm{R} 10$ & Ilogbo & 31 & Excellent & 32 & Excellent \\
\hline R11 & Okoron & 14 & Excellent & 12 & Excellent \\
\hline R12 & Iragbon & 14 & Excellent & 12 & Excellent \\
\hline R13 & Isiu & 16 & Excellent & 16 & Excellent \\
\hline R14 & Imota & 16 & Excellent & 18 & Excellent \\
\hline R15 & Gberigbe & 15 & Excellent & 14 & Excellent \\
\hline \multicolumn{6}{|c|}{ Urban settlement } \\
\hline $\mathrm{U} 1$ & Ipaja & 20 & Excellent & 23 & Excellent \\
\hline $\mathrm{U} 2$ & Baruwa & 29 & Excellent & 18 & Excellent \\
\hline U3 & Alagbado & 16 & Excellent & 13 & Excellent \\
\hline $\mathrm{U} 4$ & Oke-Odo & 11 & Excellent & 9 & Excellent \\
\hline U5 & Ejigbo & 17 & Excellent & 23 & Excellent \\
\hline U6 & Egbeda & 16 & Excellent & 20 & Excellent \\
\hline U7 & Dopemu & 36 & Excellent & 37 & Excellent \\
\hline U8 & Oko-Oba & 47 & Excellent & 44 & Excellent \\
\hline U9 & Olushosun & 39 & Excellent & 34 & Excellent \\
\hline U10 & Epe & 21 & Excellent & 18 & Excellent \\
\hline U11 & Odogunyan & 25 & Excellent & 22 & Excellent \\
\hline U12 & Ikorodu & 18 & Excellent & 18 & Excellent \\
\hline U13 & Alausa & 23 & Excellent & 16 & Excellent \\
\hline U14 & Shomolu & 38 & Excellent & 29 & Excellent \\
\hline U15 & Shogunle & 38 & Excellent & 33 & Excellent \\
\hline
\end{tabular}


groundwater quality in the area. Unlike the observed unsuitable water for drinking found at one of the sites at Igando, the deterioration of the groundwater quality can be linked to the infiltration of leachates from the nearby dumpsite into the well. The result of the present study shows that the WQI of the study area is suitable for drinking. Similar studies by Ebong et al (2017) reported the suitability of groundwater quality from Abi, southeastern Nigeria, for drinking and irrigation purposes based on WQI. The findings of Etim et al (2013) also concluded that the water sources from the borehole and pipe-borne water in the Niger-Delta region of Nigeria based on WQI are safe for human consumption and for other domestic purposes. Also, Olatunji et al (2015) reported the suitability of groundwater quality for drinking based on their study in Ilorin metropolis, Nigeria. Balogun and Adegun (2013) reported the high concentration of EC, TDS, $\mathrm{Cl}$, and trace metals in their study around Igando. A similar study by Yidana and Yidana (2010) asserts that the WQI of the Voltaian sedimentary basin in Ghana is suitable for drinking purpose.

\section{Groundwater salinization}

The result of the RI ranged between 0.1 and $22.2 \mathrm{meq} / \mathrm{L}$ in the dry season and between 0.1 and $21.8 \mathrm{meq} / \mathrm{L}$ in the wet season. The distribution of groundwater salinity in the study area shows that approximately $48.9 \%$ and $46.7 \%$ of the sampling sites in the dry season are unaffected and slightly affected by salinity, respectively. Only $4.4 \%$ of the samples sites are strongly affected by salinity (Fig. 6). The RI during the wet season indicates that $46.7 \%$ of the sampling sites are unaffected/slightly affected by salinity, while $6.6 \%$ are strongly affected by salinity (Fig. 7). The impact of salinity on the groundwater quality around Igando and Oko-Oba is indicative of the land use/ anthropogenic activities resulting from dumpsite and abattoir in the settlement, respectively. The result of the RI in the present study is attributed to land use/anthropogenic activities in the study area. A similar study by Amadi et al (2012) reported groundwater quality deterioration of the coastal aquifers of Eastern Niger-Delta Nigeria, due to salinity and anthropogenic interference.

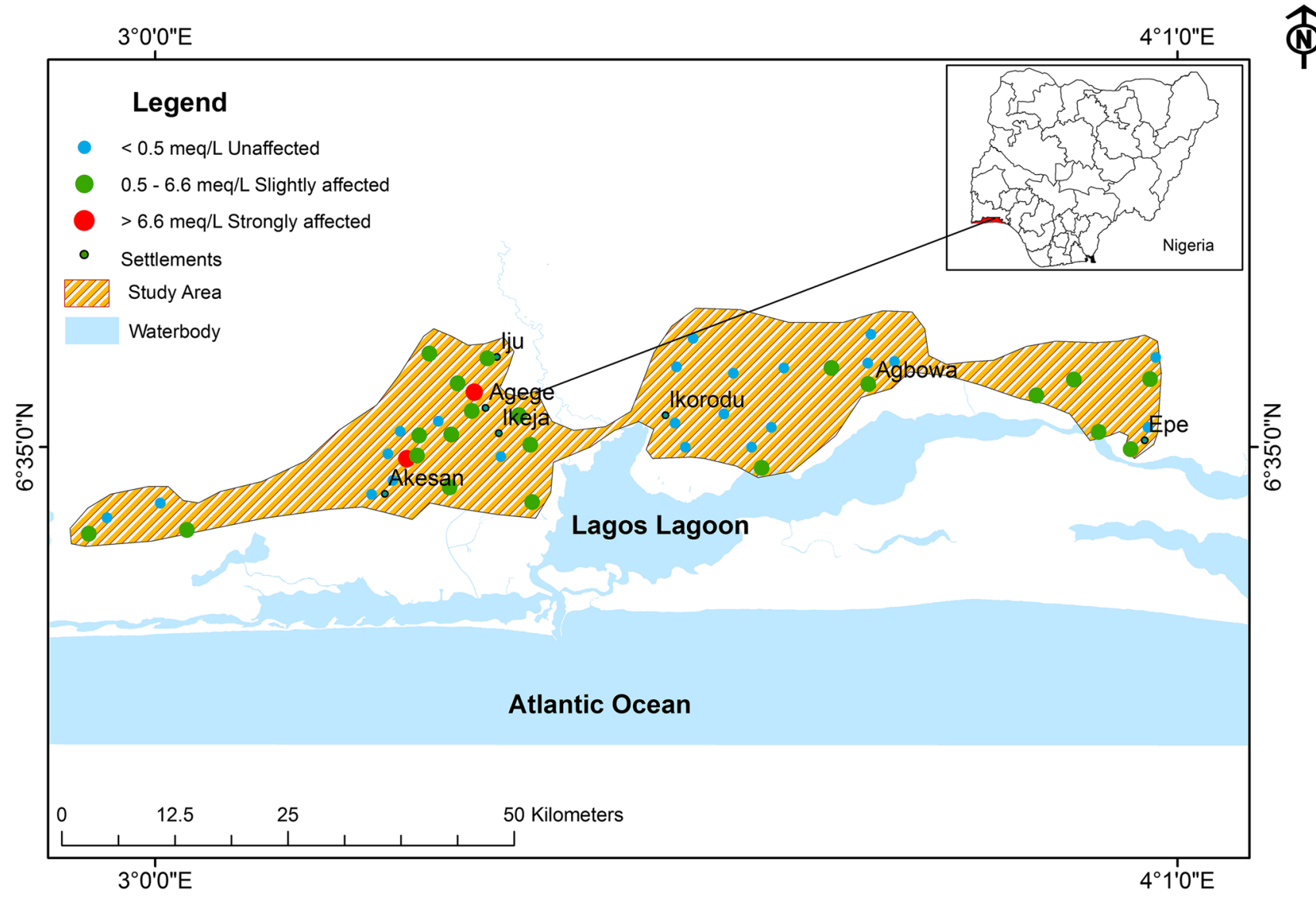

Fig. 6 Distribution of Revelle index in the dry season 


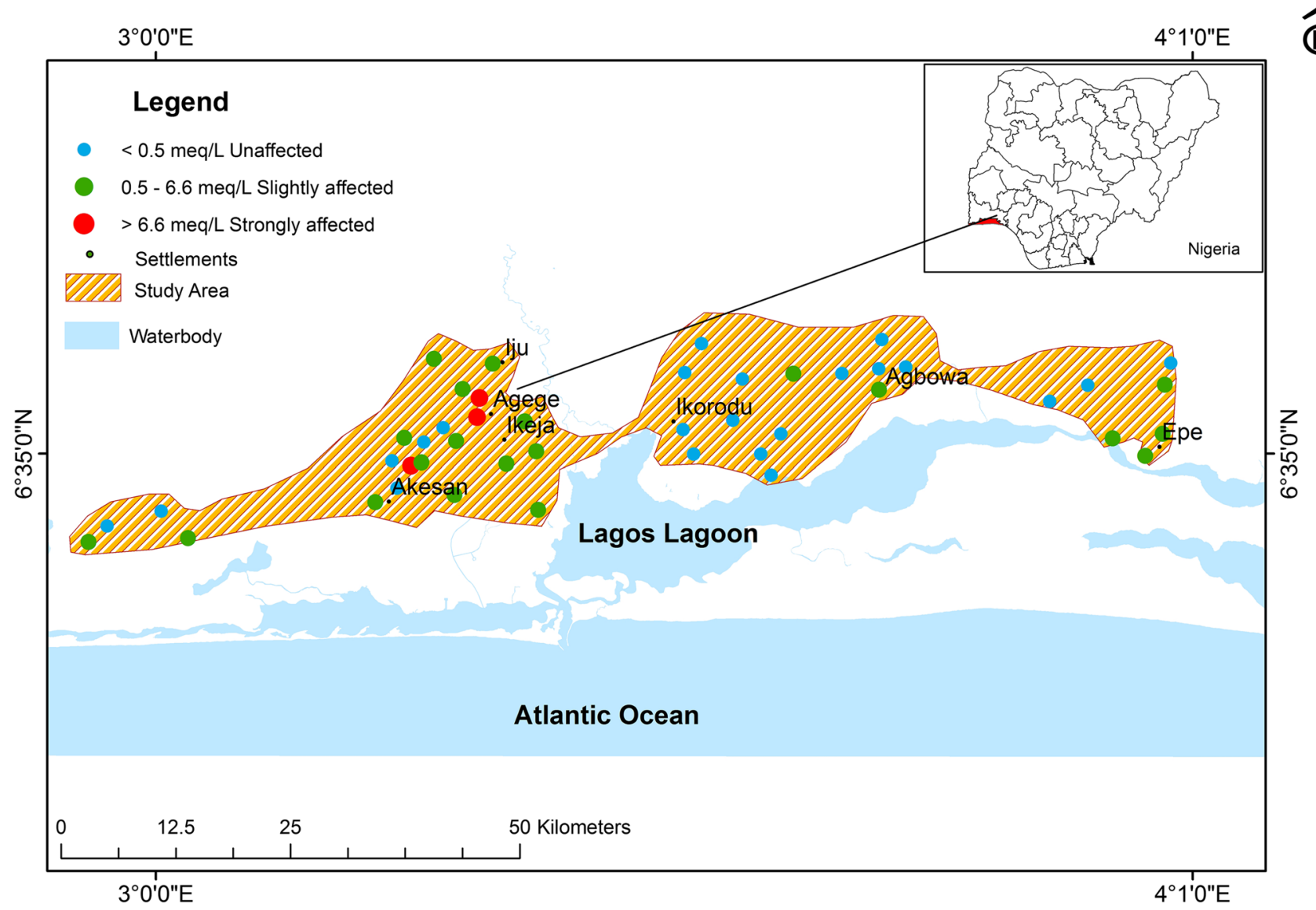

Fig. 7 Distribution of Revelle index in the wet season

\section{Water stability index}

\section{Langelier Saturation Index}

The results of the LSI varied from -5.81 to -0.16 with an average of -3.28 in the dry season. It varies from -5.52 to -1.06 with an average of -3.05 in the wet season. The dry season value of LSI shows that $31.1 \%$ of the samples indicate very severe/ moderate corrosion. About 28.9\% of the groundwater samples indicate severe corrosion, while $4.4 \%$ shows mild/slight corrosion in the dry season (Fig. 8). During the wet season, 35.6, 24.4, 22.2, and $17.8 \%$ of the samples are indicative of moderate, severe, very severe, and mild corrosion, respectively (Fig. 9). The severe cases of corrosion in the study area can be attributed to the high value of $\mathrm{pH}$, TDS, $\mathrm{TH}$, and $\mathrm{HCO}_{3}{ }^{-}$in the study sites (Gholizadeh et al. 2017). The results of the LSI show that the groundwater is corrosive due to the high value of $\mathrm{pH}$, TDS, TH, and $\mathrm{HCO}_{3}{ }^{-}$in the study area. A study conducted by Ibeneme et al (2013) on the spring water at Ife-Owutu, Southeastern based on LSI, inferred that the water is moderate to severely corrosive. Similarly,
Ozoko (2015) reported that the water sources in Abakaliki, Nigeria, are very corrosive in all the samples.

\section{Pipers plot}

\section{Characterization of Hydrochemical facies of groundwater}

The hydrochemical facies of the study area can be classified into four major categories based on the section of the diamond shape according to the classification scheme by Walton (1962). The first group is primary hardness and consists of calcium, magnesium, and bicarbonate. This water type falls within the section designated as 5 in Piper's plot. The classification shows that primary hardness accounted for $59.9 \%$ and $31.8 \%$ of the samples in the dry and wet seasons, respectively. The second class is secondary hardness and comprised of sulfate, chloride, magnesium, and calcium (Back and Hanshaw 1965; Walton 1962; Tay and Kortatsi 2008). This category is designated as 6 in Piper's plot and represents $20 \%$ and $4.5 \%$ in the dry and wet seasons, 


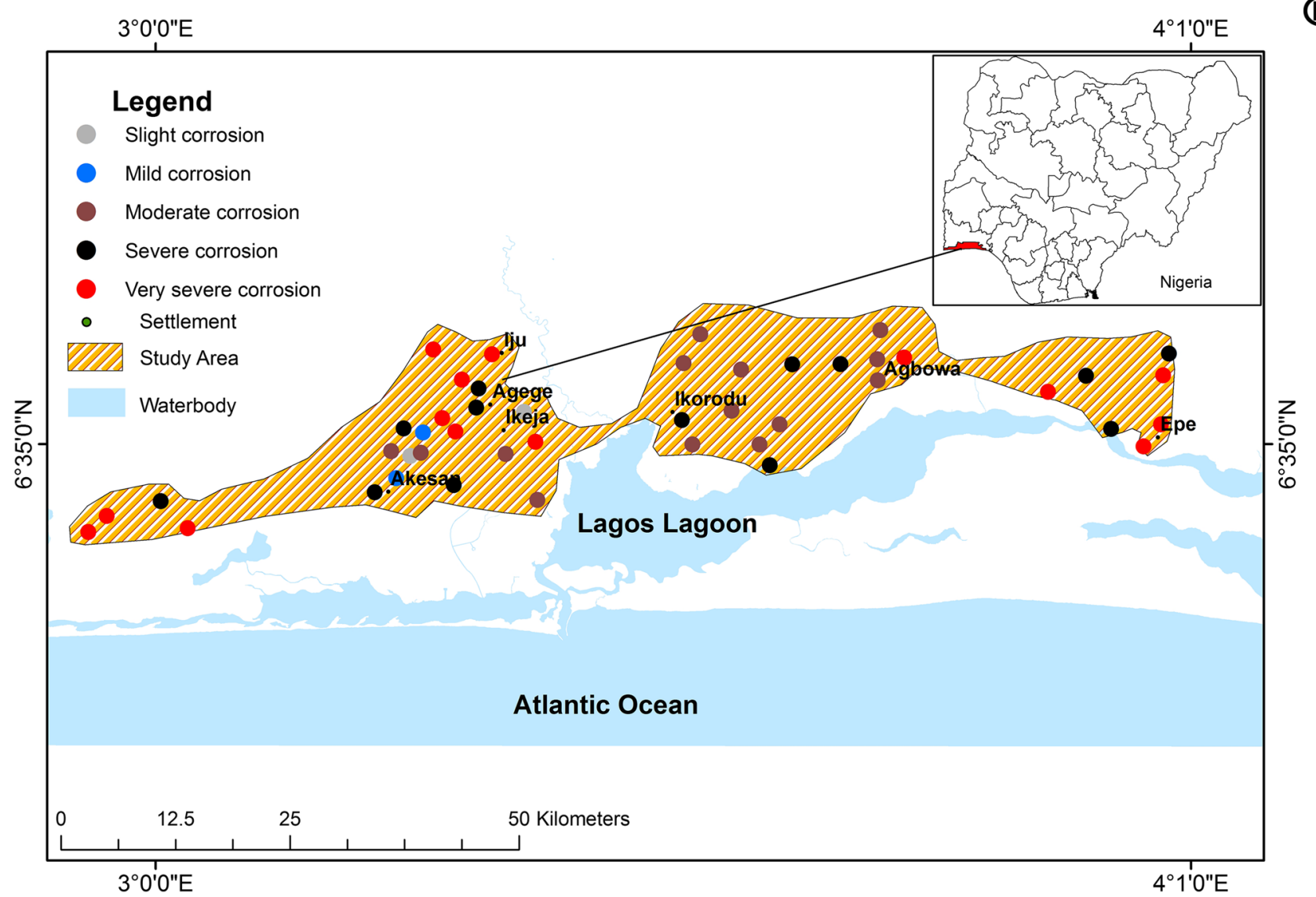

Fig. 8 Distribution of Langelier index in the dry season

respectively. The third class is known as primary salinity and comprised of alkali metals, sulfate, and chloride. This category is regarded as brackish or extreme saline water. It occupies the portion designated as 7 in Piper's plot and accounts for $22.7 \%$ and $6.7 \%$ in the wet and dry seasons, respectively. The fourth class is mixed waters which usually result from multiple mineral dissolution or mixing of chemically distinct water types (Walton 1962; Sahu et al. 2016). This group occupies the portion designated 9 in Piper's diagram. Mixed waters account for $41 \%$ and $13.4 \%$ of the samples in the wet and dry seasons, respectively (Back and Hanshaw 1965; Walton 1962; Tay and Kortatsi 2008). Based on Table 7, the four classes of the hydrochemical facies can be grouped into two major facies. The first group is the concentration of cation which is dominated by $\mathrm{Ca}-\mathrm{Na}$ type representing $87 \%$ of the samples in the dry season and $62 \%$ during the wet seasons. $\mathrm{HCO}_{3}$ water type is the second group and predominated in the dry season with $69 \%$ sample and with $67 \%$ during the wet season (Figs. 10 and 11).
A study conducted by Sahu et al. (2016) identified three major water types, namely fresh, mixed, and brackish. They inferred that the freshwater type is dominated by sodium which is indicative of active flushing of the aquifer. They concluded that chloride-rich 'brackish' represents freshening of modified connate water why the 'mixed' type evolved due to the hydraulic mixing of 'fresh' and 'brackish' waters. Ansari et al. (2015) reported the dominance of $\mathrm{Ca}-\mathrm{Mg}-\mathrm{HCO}_{3}$ and $\mathrm{Ca}-\mathrm{Mg}-\mathrm{HCO}_{3}-\mathrm{SO}_{4}$ waters in the Himalayas, India. In a similar study, Narany et al. (2014) reported that the groundwater indicates low mineralized $\mathrm{Ca}-\mathrm{HCO}_{3}, \mathrm{Ca}-\mathrm{Na}-\mathrm{HCO}_{3}$, and $\mathrm{Ca}-\mathrm{Cl}$ water types to high mineralized $\mathrm{Na}-\mathrm{Cl}$ water type. The findings of Logeshkumaran et al. (2015) indicated that the groundwater samples are dominated by $\mathrm{Na}-\mathrm{Cl}$ and mixed $\mathrm{Ca}-\mathrm{Mg}-\mathrm{Cl}$ type. Jamshidzadeh and Mirbagheri (2011) reported the dominance of $\mathrm{Na}-\mathrm{Cl}$ water type. A study by Sadashivaiah et al. (2008) also shows the predominance of $\mathrm{Ca}-\mathrm{Mg}-\mathrm{HCO}_{3}$ water type during the pre- and post-monsoon seasons in Taluk. 


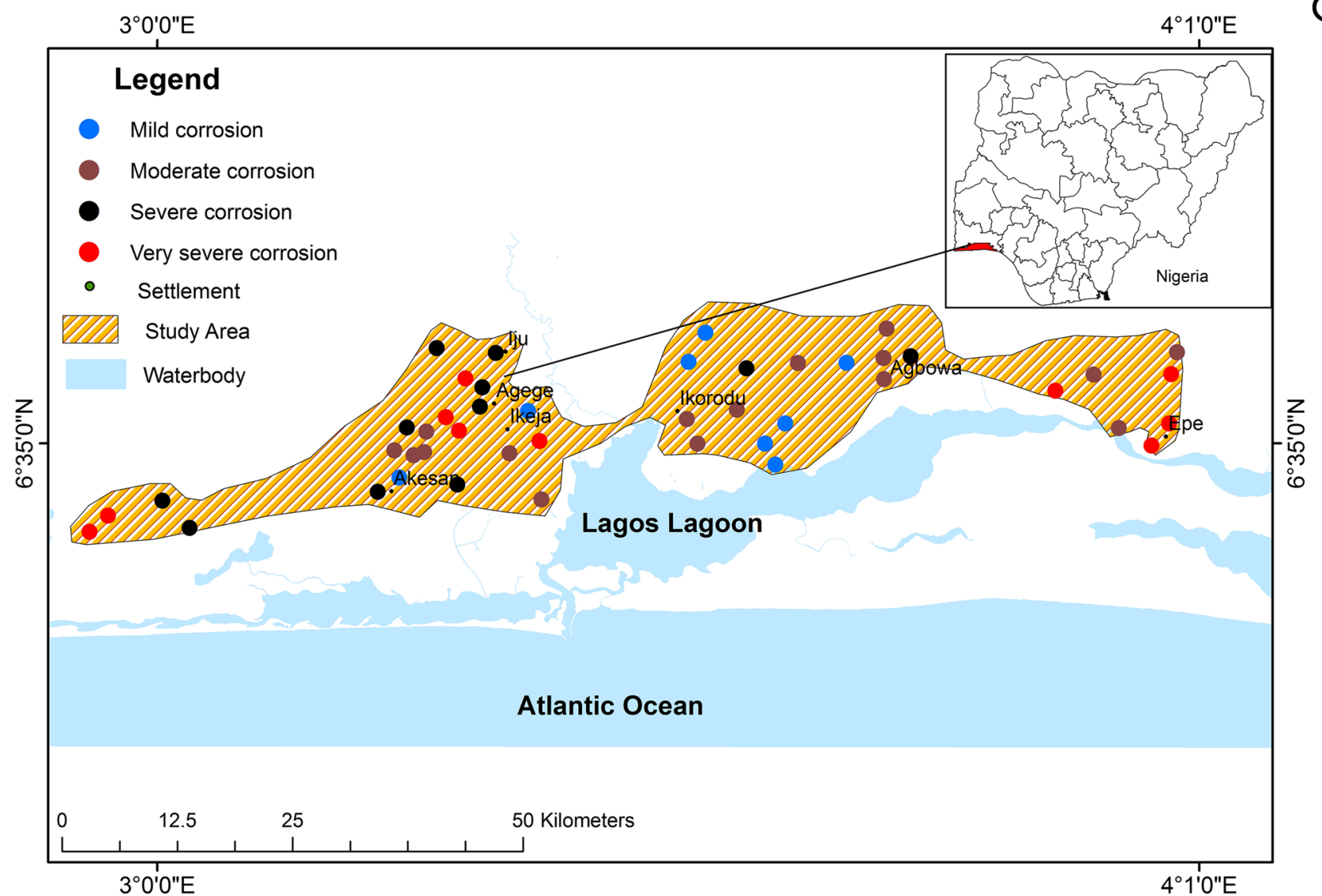

Fig. 9 Distribution of Langelier index in the wet season

Table 7 Characterization of groundwater of the study area on Piper's plot

\begin{tabular}{|c|c|c|c|}
\hline \multirow[t]{2}{*}{$\begin{array}{l}\text { Subdivision of } \\
\text { the diamond }\end{array}$} & \multirow[t]{2}{*}{ Characteristics of the subdivision of the diamond fields } & \multicolumn{2}{|c|}{$\begin{array}{l}\text { Percentage of the samples/ } \\
\text { season }\end{array}$} \\
\hline & & Dry season & Wet season \\
\hline 1 & Alkaline earth $(\mathrm{Ca}+\mathrm{Mg})$ exceeds alkalies $(\mathrm{Na}+\mathrm{K})$ & 87 & 38 \\
\hline 2 & Alkalies exceeds alkaline earths & 13 & 62 \\
\hline 3 & Weak acids $\left(\mathrm{CO}_{3}+\mathrm{HCO}_{3}\right)$ exceed strong acids $\left(\mathrm{SO}_{4}+\mathrm{Cl}\right)$ & 67 & 69 \\
\hline 4 & Strong acids exceed weak acids & 33 & 31 \\
\hline 5 & Magnesium bicarbonate type & 60 & 31.1 \\
\hline 6 & Calcium chloride type & 6.7 & 2.2 \\
\hline 7 & Sodium chloride type & 6.7 & 24.4 \\
\hline 8 & Sodium bicarbonate type & 0 & 6.7 \\
\hline 9 & Mixed type (no cation-anion exceed 50\%) & 26.6 & 35.6 \\
\hline
\end{tabular}

\section{Conclusions}

Integrated approaches to various water quality indices, chemometric methods, such as multivariate statistical analysis and geostatistical technique, are employed in this study to assess groundwater quality and the hydrochemical processes in Lagos, Nigeria. The $\mathrm{pH}$ of groundwater indicates acidic to slightly alkaline in the peri-urban and urban settlements, while in the rural area it shows acidic to moderately alkaline in the dry season. The dominant cation and anion in the rural and urban settlements are $\mathrm{Ca}^{2+}$ and $\mathrm{HCO}_{3}{ }^{-}$, while $\mathrm{Na}^{+}$and $\mathrm{Cl}^{-}$predominate in the peri-urban 
Fig. 10 Hydrochemical facies of groundwater in the dry season

Fig. 11 Hydrochemical facies of groundwater in the wet season

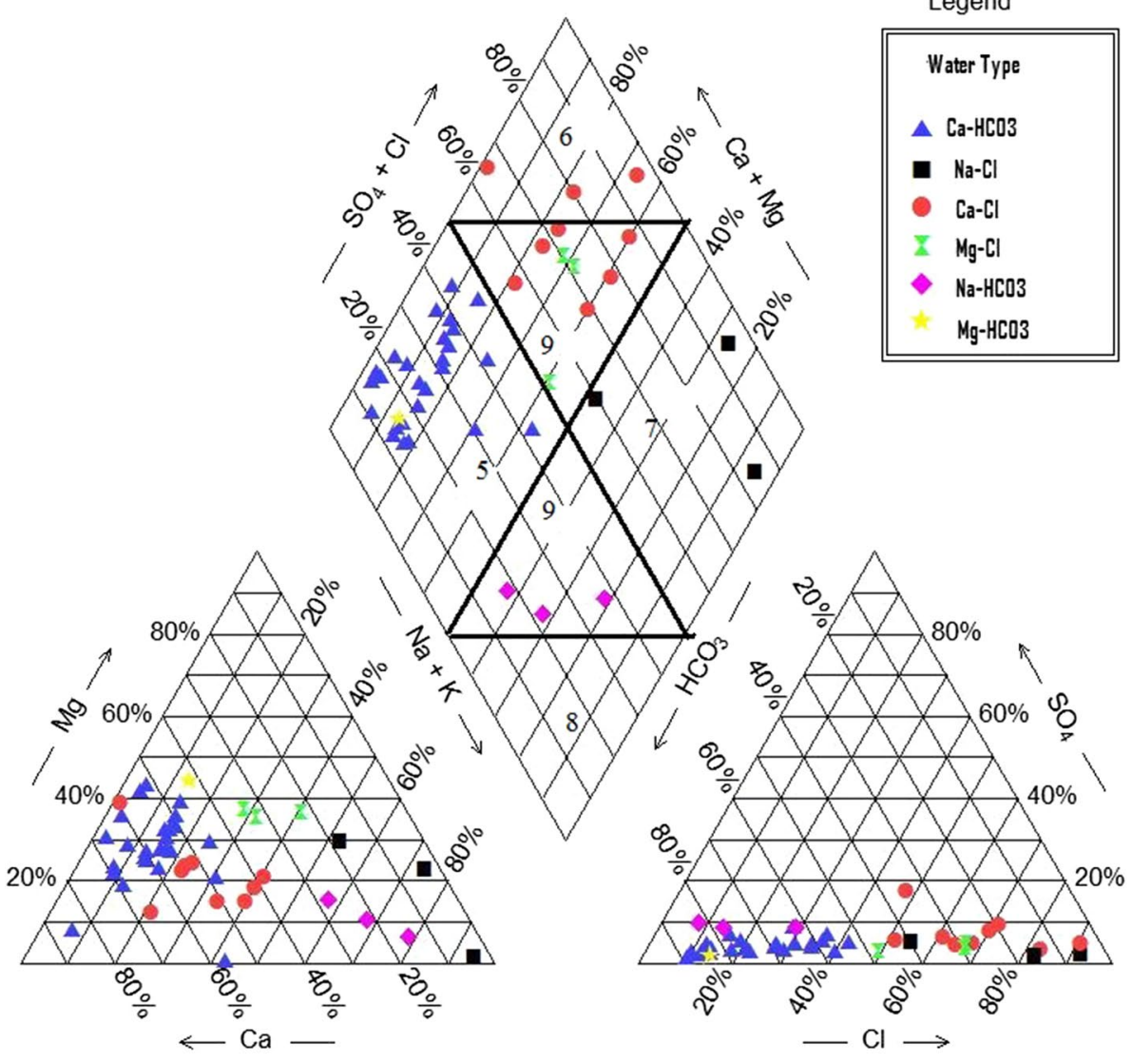

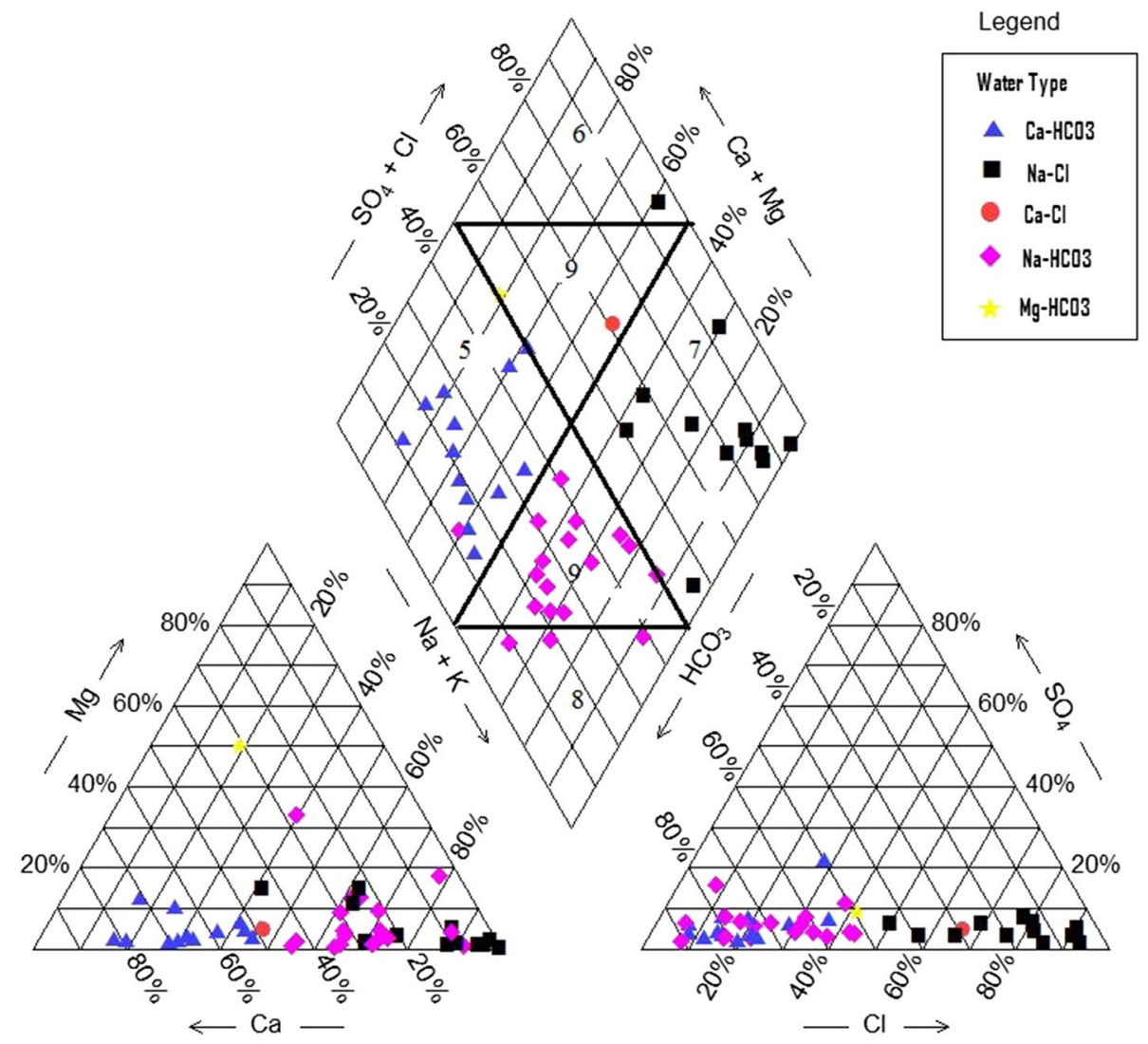


during the dry season. In the wet season, $\mathrm{pH}$ indicates moderately acidic to slightly alkaline. Sodium and chloride are the dominant cation and anion in peri-urban. The $\mathrm{pH}$ is moderately acidic to neutral in the rural, and the dominant cation and anion are $\mathrm{Na}^{+}$and $\mathrm{Cl}^{-}$. The dominant cation and anion are sodium and bicarbonate in the urban settlement. The seasonal variations of the physicochemical parameters of groundwater in the study area show that about $95.6 \%$ and $60 \%$ of the sampling sites had $\mathrm{pH}$ values below the minimum guideline for drinking water. About $2.2 \%$ of the measured EC and TDS fall under high enrichments of salts and moderately saline, respectively, in both seasons. The TH shows that $4.4 \%$ and $6.9 \%$ of the samples are very hard and moderately hard in the dry and wet seasons, respectively. The distribution of chloride shows that $2.2 \%$ of the samples indicate brackish-salt in both seasons, while bicarbonate shows that $84.4 \%$ and $66.7 \%$ of the samples fall under poor zone in the wet and dry seasons, respectively. The seasonal paired sample $T$ test shows significant variations among four parameters including $\mathrm{pH}$, $\mathrm{Ca}^{2+}, \mathrm{HCO}_{3}{ }^{-}$, and $\mathrm{Mg}^{2+}$. The result of the FA explained $73.5 \%$ and $84.2 \%$ of the total variance in the dry and wet seasons, respectively. Two major factors were extracted, namely salinity and weathering of minerals. The salinity factors result from $\mathrm{EC}$, TDS $\mathrm{Na}^{+}, \mathrm{K}^{+}, \mathrm{Cl}^{-}, \mathrm{SO}_{4}^{2}$, and anthropogenic source of pollution from leachates, sewage, and wastewater. The weathering of minerals is due to high loading of $\mathrm{Ca}^{2+}$. The mechanism controlling groundwater chemistry shows that more than $95 \%$ and $93 \%$ of the anions and cations are dominated by rock-weathering process in both seasons. The results of the drinking WQI in the dry season range between 10 and 573 and between 9 and 430 in the wet season. Approximately $95.6 \%$ and 2.2\% of the sampling sites have excellent/good water quality, while $2.2 \%$ indicates unsuitable water for drinking in the dry season.

The wet season WQI in all the sites has excellent water quality except one site at Igando indicating unsuitable water for drinking. The observed unsuitable water for drinking in the study area is attributed to the land use resulting from dumpsite. The RI ranged between 0.1 and $22.2 \mathrm{meq} / \mathrm{L}$ in the dry season and between 0.1 and $21.8 \mathrm{meq} / \mathrm{L}$ in the wet season. The distribution of the RI shows that only $4.4 \%$ of the samples sites are strongly affected in the dry season. The wet season RI indicates $6.6 \%$ of the samples are strongly affected by salinity. The impact of salinity is indicative of the land use/ anthropogenic activities resulting from dumpsite and abattoir in the study area. The results of the LSI varied from -5.81 to -0.16 with an average of -3.28 in the dry season. During the wet season, LSI varies from -5.52 to -1.06 with an average of -3.05 in the wet season. About $31.1 \%$ and $28.9 \%$ of the samples indicate very severe/severe in the dry season. During the wet season, $22.2 \%$ and $24.4 \%$ of the samples are indicative of severe and severe corrosion, respectively. The severe cases of corrosion in the study area can be attributed to the high value of $\mathrm{pH}$, TDS, TH, and $\mathrm{HCO}_{3}{ }^{-}$. The cation concentration is dominated by $\mathrm{Ca}-\mathrm{Mg}$ water type in the dry season, while $\mathrm{Na}-\mathrm{K}$ type predominates in the wet season. The anion shows that $\mathrm{HCO}_{3}$ water type predominated in both seasons. The hydrochemical facies of the study area were grouped into four categories. The primary hardness accounted for $59.9 \%$ and $31.8 \%$ of the samples in the dry and wet seasons, respectively. Secondary hardness represents $20 \%$ and $4.5 \%$ in the dry and wet seasons, respectively. Primary salinity accounts for $22.7 \%$ and $6.7 \%$ in the wet and dry seasons, respectively. Mixed waters account for $41 \%$ and $13.4 \%$ of the samples in the wet and dry seasons, respectively. The findings revealed that the groundwater quality is suitable for drinking. Leachates, salinity, and land use constitute a major threat to groundwater sustainability in the study area. The study contributes to knowledge in mapping the distributional patterns of groundwater salinization and water stability index. It also identified the major mechanism controlling groundwater chemistry, sources of groundwater pollution and delineation of water types in the study area as baseline information for effective groundwater management.

Acknowledgements The authors wish to thank the anonymous reviewers for their constructive comments, suggestions, and contributions, which have greatly improved the quality of the manuscript.

\section{Compliance with ethical standards}

Conflict of interest We the authors declared that we have no competing interests and that all the authors have seen and approved the revised version of this manuscript.

Open Access This article is distributed under the terms of the Creative Commons Attribution 4.0 International License (http://creativeco mmons.org/licenses/by/4.0/), which permits unrestricted use, distribution, and reproduction in any medium, provided you give appropriate credit to the original author(s) and the source, provide a link to the Creative Commons license, and indicate if changes were made.

\section{References}

Abdel Latif A, El Kashouty M (2010) Groundwater investigation in Awlad Salameh, Southern Sohag, Upper Egypt. Earth Sci Res J 14(1):63-75

Adepelumi AA (2009) Delineation of saltwater intrusion into the freshwater aquifer of Lekki Peninsula, Lagos, Nigeria. Environ Geol 56(5):927-933

Akoteyon IS (2013) Hydrochemical studies of ground water in parts of Lagos, Southwestern Nigeria. Bull Geogr Phys Geogr Ser 6(1):27-42

Akoteyon IS, Ogundele FO, Soladoye O (2010) Characterization by factor analysis of groundwater in the coastal plain sand aquifer of Lagos, South West Nigeria. Int J Acad Res 2(5):256-260

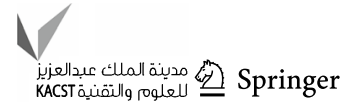


Alsaqqar AS, Khudair BH, Ali SK (2014) Evaluating water stability indices from water treatment plants in Baghdad City. J Water Res Prot 6(14):1344-1351

Amadi AN, Olasehinde PI, Yisa J, Okosun EA, Nwankwoala HO, Alkali YB (2012) Geostatistical assessment of groundwater quality from coastal aquifers of Eastern Niger Delta, Nigeria. Geosciences 2(3):51-59

American Public Health Association (1998) American Waterworks Association. Water Environmental Federation. In: Standard method for the examination of water and wastewater, 20th edn. Washington, DC

Ansari A, Deodhar A, Saravana UK, Khatti VS (2015) Water quality of few springs in outer Himalayas: a study on the groundwaterbedrock interactions and hydrochemical evolution. Groundw Sustain Dev 1(1-2):59-67

Apello J, Postma D (2005) Geochemistry, groundwater and pollution, 2nd edn. CRC Press, London

Arian MB, Kazi TG, Jamal MK, Jalbani N, Afridi HI, Shah A (2008) Total dissolved and bio available elements in water and sediment samples and their accumulation in Oreochromis mossambicus of polluted Manchar Lake. Chemosphere 70(10):1845-1856

Aris AZ, Abdullah MH, Praveena SM (2009) Evolution of groundwater chemistry in the shallow aquifer of a small tropical Island in Sabah. Sains Malays 38(6):805-812

Back W, Hanshaw BB (1965) Advances in hydro-science. Chem Geohydrol 11:49

Balogun I, Adegun O (2013) Seasonal evaluation of groundwater quality around Igando dumpsites in Lagos metropolis using correlation and regression analysis. J Appl Sci Environ Manag 17(2):329-333

Balogun II, Akoteyon IS, Adeaga O (2012) Evaluating land use effects on groundwater quality in Lagos-Nigeria using water quality index. J Sci Res 4(2):397-409

Bharti N, Katyal D (2011) Water quality indices used for surface water vulnerability assessment. Inter J Environ Sci 2(1):154-173

Bhattacharya P, Bundschuh J (2015) Groundwater for sustainable development - cross cutting the UN sustainable development goals-editorial. Groundwater Sustainable Dev 1(1-2):155-157

Boateng TK, Opoku F, Acquaah SO, Akoto O (2016) Groundwater quality assessment using statistical approach and water quality index in Ejisu-Juaben Municipality, Ghana. Environ Earth Sci 75(6):489

Bu H, Xiang T, Siyue L, Quanfa Z (2010) Temporal and spatial variations of water quality in the Jinshui River of the South Qinling Mts., China. Ecotoxicol Environ Saf 73(5):907-913

Carroll D (1962) Rainwater as a chemical agent of geologic processes: a review. US Government Printing Office, Washington, DC

Choi J, Choi BG, Hong S (2015) Effects of NF treated water on corrosion of pipe distribution system and its implications to blending with conventionally treated water. Desalination 360:138-145

Chung WS, Yu MJ, Lee HD (2004) Prediction of corrosion rates of water distribution pipelines according to aggressive corrosive water in Korea. Water Sci Technol 49(2):19-26

Collins WD (1923) Graphic representation of analyses. Ind Eng Chem 15(4):394

Coode B, Rofe K, Lapworth S (1997) Hydrogeological investigation of Lagos State. Lagos State Water Corporation, Final report 2, pp 86

Dalton MG, Upchurch SB (1978) Interpretation of hydrochemical facies by factor analysis. Groundwater 16(4):228-233

Durov SA (1948) Natural waters and graphic representation of their composition. Dokl Akad Nauk SSSR 59(3):87-90

Ebong ED, Akpan AE, Emeka CN, Urang JG (2017) Groundwater quality assessment using geoelectrical and geochemical approaches: case study of Abi area, southeastern Nigeria. Appl Water Sci 7(5):2463-2478
Etim EE, Odoh R, Itodo AU, Umoh SD, Lawal U (2013) Water quality index for the assessment of water quality from different sources in the Niger Delta Region of Nigeria. Front Sci 3(3):89-95

Fournier RO (1981) Application of water geochemistry to geothermal exploration and reservoir engineering. In: Ryback L, Muffler LJP (eds) Geothermal systems: principles and case histories. John Wiley \& Sons, New York, pp 109-143

Gholizadeh A, Mokhtari M, Naimi N, Shiravand B, Ehrampoush MH, Miri M, Ebrahimi A (2017) Assessment of corrosion and scaling potential in groundwater resources; a case study of Yazd-Ardakan Plain, Iran. Groundw Sustain Dev 5:59-65

Gibbs RJ (1970) Mechanisms controlling world water chemistry. Science 170(3962):1088-1090

Gleick PH (2002) Dirty-water: estimated deaths from water-related diseases 2000-2020. Pacific Institute for Studies in Development, Environment, and Security, Oakland

Gupta N, Nafees SM, Jain MK, Kalpana S (2011) Assessment of groundwater quality of outer skirts of Kota City with reference to its potential of scale formation and corrosivity. J Chem 8(3):1330-1338

Howladar MF, Al Numanbakth A, Faruque MO (2017) An application of water quality index (WQI) and multivariate statistics to evaluate the water quality around Maddhapara granite mining industrial area, Dinajpur, Bangladesh. Environ Syst Res 6(1):13

Ibeneme SI, Ukiwe LN, Essien AG, Nwagbara JO, Nweze CA, Chinemelu ES, Ivonye CA (2013) Assessment of the chemical characteristics of a spring water source at Ife-Owutu, Ezinihite-Mbaise, Southeastern Nigeria. Am J Eng Res 2(10):282-290

Jalali M, Kolahchi Z (2008) Groundwater quality in an irrigated, agricultural area of northern Malayer, western Iran. Nutr Cycl Agroecosyst 80(1):95-105

Jamshidzadeh Z, Mirbagheri SA (2011) Evaluation of groundwater quantity and quality in the Kashan Basin, Central Iran. Desalination $270(1-3): 23-30$

Kumazawa K (2002) Nitrogen fertilization and nitrate pollution in groundwater in Japan: present status and measures for sustainable agriculture. Nutr Cycl Agroecosyst 63(2-3):129-137

Kurdi M, Ferdows MS, Maghsoudi A (2015) Sensitivity of corrosion and scaling indices based on ions; case study Iran. Water Qual Expo Health 7(3):363-372

Langelier WF, Ludwig HF (1942) Graphical methods for indicating the mineral character of natural waters. J (Am Water Works Assoc) 34(3):335-352

Lobo Ferreira JP, Chachadi AG, Diamantino C, Henriques MJ (2005) Assessing aquifer vulnerability to sea-water intrusion using Galdit method: Part 1-application to the Portuguese aquifer of Monte Gordo. Comunicação apresentada no $4^{\circ}$ Intercéltico" Water in Celtic Countries: Quantity, Quality and Climate Variability", Guimarães, 11 a 14 de Julho de 2005

Logeshkumaran A, Magesh NS, Godson PS, Chandrasekar N (2015) Hydro-geochemistry and application of water quality index (WQI) for groundwater quality assessment, Anna Nagar, part of Chennai City, Tamil Nadu, India. Appl Water Sci 5(4):335-343

Lu KL, Liu CW, Jang CS (2012) Using multivariate statistical methods to assess the groundwater quality in an arsenic-contaminated area of Southwestern Taiwan. Environ Monit Assess 184(10):6071-6085

Machiwal D, Jha MK (2015) Identifying sources of groundwater contamination in a hard-rock aquifer system using multivariate statistical analyses and GIS-based geostatistical modeling techniques. J Hydrol Region Stud 4:80-110

Maeng M, Hyun I, Choi S et al (2015) Effects of rainfall characteristics on corrosion indices in Korean river basins. Desalination Water Treat 54(4-5):1233-1241

Narany ST, Ramli MF, Aris AZ, Sulaiman WN, Juahir H, Fakharian $K$ (2014) Identification of the hydrogeochemical processes in 
groundwater using classic integrated geochemical methods and geostatistical techniques, in Amol-Babol plain, Iran. Sci World J 2014:1-15

Ocheri MI, Odoma LA, Umar ND (2014) Groundwater quality in Nigerian urban areas: a review. Global J Sci Front Res H Environ Earth Sci 14:35-45

Olatunji JA, Odediran OA, Obaro RI, Olasehinde PI (2015) Assessment of groundwater quality of ilorin metropolis using water quality index approach. Niger J Technol Dev 12(1):18-21

Ozoko DC (2015) Corrosion potentials of natural waters in Abakaliki, Ebonyi State, Nigeria. J Nat Sci Res 5(9):108-114

Piper AM (1944) A graphic procedure in the geochemical interpretation of water analyses. Trans Am Geophy Union Trans 25(6):914-923

Prasanna MV, Chidambaram S, Srinivasamoorthy K, Anandhan P, John Peter A, Senthil Kumar G (2008) Evaluation of mechanisms controlling hydrogeochemical nature of groundwater in Gadilam river basin, Tamilnadu, India. Icfai J Earth Sci 2(1):47-60

Raju NJ, Patel P, Gurung D, Ram P, Gossel W, Wycisk P (2015) Geochemical assessment of groundwater quality in the Dun valley of central Nepal using chemometric method and geochemical modeling. Groundw Sustain Dev 1(1-2):135-145

Rao NS (2002) Geochemistry of groundwater in parts of Guntur district, Andhra Pradesh, India. Environ Geol 41(5):552-562

Rao NS, Rao PS, Reddy GV, Nagamani M, Vidyasagar G, Satyanarayana NL (2012) Chemical characteristics of groundwater and assessment of groundwater quality in Varaha River Basin, Visakhapatnam District, Andhra Pradesh, India. Environ Monit Assess 184(8):5189-5214

Revelle R (1941) Criteria for recognition of sea water in ground-waters. EOS Trans Am Geophys Union 22(3):593-597

Robinson C, Barry DA, McCarty PL, Gerhard JI, Kouznetsova I (2009) $\mathrm{pH}$ control for enhanced reductive bioremediation of chlorinated solvent source zones. Sci Total Environ 407(16):4560-4573

Sadashivaiah C, Ramakrishnaiah CR, Ranganna G (2008) Hydrochemical analysis and evaluation of groundwater quality in Tumkur Taluk, Karnataka State, India. Int J Environ Res Public Health 5(3): 158-164

Sahu P, Sikdar PK (2008) Hydrochemical framework of the aquifer in and around East Kolkata Wetlands, West Bengal. India Environ Geol 55(4):823-835

Sahu P, Sikdar PK, Chakraborty S (2016) Geochemical evolution of groundwater in southern Bengal Basin: the example of Rajarhat and adjoining areas, West Bengal, India. J Earth Syst Sci 125(1):129-145

Salami L, Susu AA (2013) Leachate characterization and assessment of groundwater quality: a case of Soluos dumpsite, Lagos, Nigeria. Greener J Sci Eng Technol Res 3(2):42-61

Sarala TD, Uma Mageswari TS (2014) Water quality indices as indicators for potable water. Desalination Water Treat 52(25-27):4772-4782

Schoeller H (1964) La classification géochimique des eaux. IASH Publ $4: 16-24$
Singh KP (1994) Temporal changes in the chemical quality of groundwater in Ludhiana area, Punjab, India. Curr Sci 10:375-378

Srinivasamoorthy K, Chidambaram S, Prasanna MV, Vasanthavihar M, John P, Anandhan P (2008) Identification of major sources controlling groundwater chemistry from a hard rock terrain: a case study from Mettur Taluk, Salem district, Tamil Nadu, India. J Earth Syst Sci 117(1):49-58

Srinivasamoorthy K, Gopinath M, Chidambaram S, Vasanthavigar M, Sarma VS (2014) Hydrochemical characterization and quality appraisal of groundwater from Pungar sub basin, Tamil Nadu, India. J King Saud Univ Sci 26(1):37-52

Stiff HA Jr (1951) The interpretation of chemical water analysis by means of patterns. J Petrol Technol 3(10):15-23

Stuyfzand PJ (1989) A new hydrochemical classification of water types. IAHS Publ 182:89-98

Tay C, Kortatsi B (2008) Groundwater quality studies: a case study of the Densu Basin, Ghana. West Afr J Appl Ecology 12(1):81-99

Todd DK, Larry WM (2005) Groundwater hydrology, 3rd edn. Wiley, Hoboken, p 636

Tziritis E, Kelepertzis A, Stamatakis M (2009) Hydrogeochemical conditions and groundwater quality in the SE part of Samos Island. Miner Wealth 149:17-27

Vincy MV, Brilliant R, Pradeepkumar AP (2015) Hydrochemical characterization and quality assessment of groundwater for drinking and irrigation purposes: a case study of Meenachil River Basin, Western Ghats, Kerala, India. Environ Monit Assess 187(1):4217-4235

Walton WC (1962) Selected analytical methods for well and aquifer evaluation. Bulletin (Illinois State Water Survey) no. 49. Illinois state water survey, pp 70-72

World Health Organization (WHO) (2011) Guidelines for drinkingwater quality. World Health Organization, Geneva

WWAP UN (2003) United Nations World Water Assessment Programme. In: The world water development report 1: water for people, water for life

Yidana SM, Yidana A (2010) Assessing water quality using water quality index and multivariate analysis. Environ Earth Sci 59(7):1461-1473

Yidana SM, Banoeng-Yakubo B, Sakyi PA (2012) Identifying key processes in the hydrochemistry of a basin through the combined use of factor and regression models. J Earth System Sci 121(2):491-507

Zhou F, Huang GH, Guo H, Zhang W, Hao Z (2007) Spatio-temporal patterns and source apportionment of coastal water pollution in eastern Hong Kong. Water Res 41(15):3429-3439

Publisher's Note Springer Nature remains neutral with regard to jurisdictional claims in published maps and institutional affiliations. 